\title{
Prudence, STRAnded Assets, AND THE REGULATION OF UTILITIES: \\ A REVIEW OF AlBERTA UTILITY REgUlatoRY Principles in a Post-Stores Block ERA
}

\author{
LOU CuSANO, DAVID WOOD, \\ EVAN DICKINSON, AND GINO BRUNI*
}

\begin{abstract}
Stores Block, a 2006 Supreme Court of Canada case, established that utilities are the sole owners of utility assets, thereby granting them the right to gain on the disposition of such assets. The case was game-changing, spawning a string of Alberta Court of Appeal, Supreme Court of Canada, and regulatory body decisions. This article traces the progression of these decisions and examines their implications for property ownership principles, including utility asset dispositions, utility rate bases, the prudent investment test, and stranded assets. The authors ultimately argue that these interpretations of Stores Block have led to "deleterious effects" for regulated utilities in Alberta, and discuss resulting attempts at legislative intervention by the Government of Alberta.
\end{abstract}

\section{TABLE OF CONTENTS}

I. INTRODUCTION . . . . . . . . . . . . . . . . . . . . . . . . . . . . 404

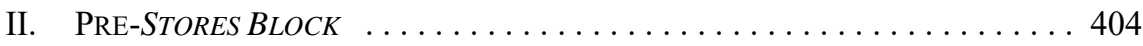

A. Return on RATE BASE AND PRUdency .............. 404

B. SAle of PRoperty OUtSide the ORdinary COURSE

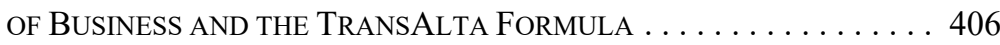

III. STORES BLOCK . . . . . . . . . . . . . . . . . . . . . 408

IV. POST-STORES BLOCK DeCiSIONS . . . . . . . . . . . . . . . . . . . . . 412

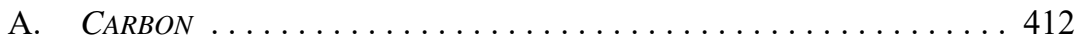

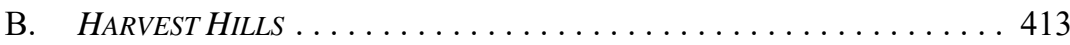

C. SaLt CaVERnS ............................. 415

V. Utility AsSET Disposition Decisions $\ldots \ldots \ldots \ldots \ldots \ldots \ldots \ldots . \ldots \ldots$

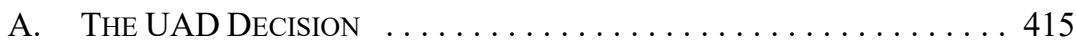

B. THe UAD APPEAL $\ldots \ldots \ldots \ldots \ldots \ldots \ldots \ldots \ldots \ldots \ldots \ldots \ldots \ldots$

VI. Post-UAD COMMISSION DECISIONS $\ldots \ldots \ldots \ldots \ldots \ldots \ldots \ldots \ldots \ldots . \ldots 421$

A. Slave Lake Fires Decision $\ldots \ldots \ldots \ldots \ldots \ldots \ldots \ldots \ldots \ldots \ldots$

B. SOUthern Alberta Floods Decision $\ldots \ldots \ldots \ldots \ldots \ldots . \ldots 423$

C. AMI Meter Decisions . . . . . . . . . . . . . . . . . . . . . . 424

VII. The AUC ApPears UnLIKely to Change Its Position . . . . . . . . . . 429

VIII. IN ITS INTERPRETATION OF STORES BLOCK

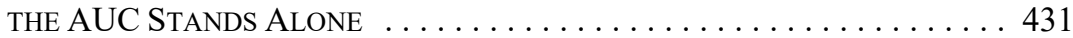

IX. Stranded AsSet Risk - Where Do We Stand TOdAY

AS A RESUlt of THE STORES BLOCK Line OF CASES? . . . . . . . . . . 432

A. THE EXTRAORDINARY RETIREMENT TEST

— Future ReCOVERy DEPENDS ON RETIREMENT History . . . . . 433

Lou Cusano is a partner at Torys LLP, David Wood is senior counsel at Torys LLP, Evan Dickinson is a senior associate at Torys LLP, and Gino Bruni is an associate at Torys LLP. The authors would like to thank Aaron Zambonin for his research and assistance in the preparation of this article. 
B. THE EXTRAORDINARY RETIREMENT TEST

— IMPLICATIONS FOR INVESTMENT IN NEW TECHNOLOGY . . . . . . 434

C. Is the No-Hindsight Prudence Test Dead? . . . . . . . . . . . . . 437

D. No COMPENSATION FOR STRANDED ASSET RISK . . . . . . . . . . . 439

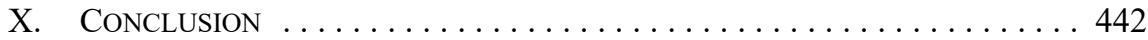

XI. A New CHAPTER? . . . . . . . . . . . . . . . . . . . . . . . . . . . . . . . . . . . . 443

\section{INTRODUCTION}

On 26 November 2013 the Alberta Utilities Commission (the Commission or the AUC) issued a decision that sent shockwaves through the boardrooms of Alberta regulated electricity and gas utilities, and energized the pens of credit rating agencies. Half a decade on, the implications and boundaries of principles laid out in this decision are still actively being explored. Known as the Utility Asset Disposition (UAD) Decision, it was one of several decisions building on and interpreting the Supreme Court of Canada's 2006 Stores Block ruling. ${ }^{1}$ The UAD Decision altered the expectations and understanding of both utilities and ratepayers regarding the financial consequences of stranded utility assets, ${ }^{2}$ an understanding that had been in place for as long as utilities have been regulated in Alberta.

The road to the UAD Decision began in 2006 with Stores Block. In that decision, the Court recognized that in accordance with fundamental corporate and property law principles, the ownership of utility assets, and thus the right to any gain upon their disposition, resided solely with utilities. ${ }^{3}$ Stores Block triggered a number of regulatory, Alberta Court of Appeal, and Supreme Court of Canada decisions as utilities, regulators, and ratepayers grappled with the implications of the property ownership principles set out in Stores Block. In Alberta, these implications have included the handling of utility asset dispositions, the concept of utility rate base, the prudent investment test, and the treatment of stranded assets.

This article seeks to explore the evolution of these issues from Stores Block to the UAD Decision and beyond. In the first part of the article we review the development of jurisprudence and regulatory decisions from the pre-Stores Block era to the present day, with a particular focus on the evolution of the treatment of the regulatory concepts described above. The article then considers the implications of the path taken by the Commission, including possible unintended consequences for both utilities and ratepayers, as well as potential future developments in response to the UAD Decision.

\section{Pre-Stores Block}

\section{A. Return on Rate Base and Prudency}

It has long been a principle in Canadian law that utilities are entitled to a reasonable opportunity to recover their prudently incurred costs and expenses, and to earn a fair return

ATCO Gas and Pipelines Ltd v Alberta (Energy and Utilities Board), 2006 SCC 4 [Stores Block]. An asset is "stranded" if it is removed from service before the end of its presumed life (that is, before it has been completely depreciated). Assets may be stranded because they have been destroyed, or if they are replaced to accommodate the adoption of new technologies, for example.

Stores Block, supra note 1 at para 69. 
on behalf of their investors. In exchange for this right, and the right of exclusivity of service, utilities are obliged to provide "safe," adequate, and reliable service at "reasonable rates" to all customers within their service territory. ${ }^{4}$ This principle, often referred to as "the "regulatory compact," Canada. While each Canadian province has legislation governing the regulation of public utilities, not all aspects of the regulatory compact are explicitly addressed in that legislation.

Utilities have been subject to rate regulation in Alberta since the Board of Public Utilities Commissioners was created by The Public Utilities Act in $1915 .{ }^{6}$ Since its inception, the principal function of the Board of Public Utilities Commissioners and each of its successors has been the determination and fixing of reasonable rates for utility service. ${ }^{7}$ Although there are different ratemaking models (such as cost of service and performance-based regulation ${ }^{8}$ ), the resulting rates must provide the utility with a reasonable opportunity to recover its prudent costs and a fair return. ${ }^{9}$ A utility's cost of service includes the costs required to operate and maintain its assets (generally referred to as operating and maintenance or O\&M costs). It also includes the cost of the assets themselves, often referred to as plant. Utilities generally finance capital assets using a mix of debt and equity in proportion to the capital structure approved by the regulator, and they are entitled to a return on and a return of capital. The return on capital is in the form of a return on equity (ROE) set by the regulator. The return of capital is achieved through the recovery of depreciation expense through utility rates. ${ }^{10}$ Utilities are also entitled to recover the interest they pay on debt issued to finance plant. All of the costs, expenses, and returns that a utility has a right to recover, as approved by its regulator, make up the utility's revenue requirement. This is the utility's revenue pie. The application of rate design principles determines how the pie is divided among the various rate classes, but the utility is always entitled to an opportunity to recover the whole pie from its ratepayers.

The ROE is the utility's profit. Utilities only earn a return on that portion of plant that is financed with equity. There is no return on O\&M (although if a utility spends less on O\&M than the amount assumed in the approved revenue requirement, it will earn more than the approved ROE). A utility's "rate base" is generally equal to its total capital investment less accumulated depreciation, ${ }^{11}$ and the ROE is calculated on the equity-funded portion of its rate base balance.

Northwestern Utilities Ltd v City of Edmonton, [1929] SCR 186 at 192-93; Stores Block, ibid at paras 60, 63-64.

Stores Block, ibid at para 63.

Ibid at para 55; The Public Utilities Act, SA 1915, c 6 [PUA 1915].

Stores Block, ibid at para 65.

Under cost of service regulation, the regulator approves a revenue requirement that is based on a reasonable forecast of the costs the utility expects to incur during the "test period" (the period for which the rates are approved) to provide utility service. Under performance-based regulation (PBR), the regulator approves going-in rates for the first year of the test period, and then in subsequent years of the test period, the revenue requirement is adjusted using a formula that changes the rates or revenue requirement by inflation less a productivity factor. The test period for cost of service rates is typically one or two years, while the test period for PBR rates is generally longer (such as five years).

Stores Block, supra note 1 at paras 63, 66.

Depreciation is the process by which the cost of a capital asset is allocated over its useful life. This cost is recovered through depreciation expense, calculated using depreciation rates approved by the regulator. These rates may differ from the rates permitted under income tax legislation.

This is a simplified explanation that ignores the effect of customer contributions or no-cost capital, for example, but it is sufficiently accurate for the purposes of this article. 
A utility's right to a reasonable opportunity to recover its costs and expenses and a fair return applies only to costs and expenses that are prudent, reasonable and prudent, or prudently incurred. ${ }^{12}$ The language varies from statute to statute, but the underlying principle is that utilities risk the disallowance of costs and expenses that the regulator determines were imprudent. The long-standing test for prudence in Alberta is as follows:

[A] utility will be found prudent if it exercises good judgment and makes decisions which are reasonable at the time they are made, based on information the owner of the utility knew or ought to have known at the time the decision was made. In making decisions, a utility must take into account the best interests of its customers, while still being entitled to a fair return. ${ }^{13}$

The reference to "at the time it was made" means that the test for prudence was not based on the application of hindsight. ${ }^{14}$ As such, once an expenditure on an asset or a capital investment was found to have been prudently incurred, it remained a prudent investment, and therefore part of rate base, until such time as it was either fully depreciated, or the utility elected to remove the asset from rate base. This is known as the no-hindsight prudent investment test. For example, under this test, if a regulator approved the cost of a new transmission line and allowed that cost to be included in rate base, the utility would be entitled to a reasonable opportunity to recover depreciation expense and ROE in respect of that transmission line, even if, for example, that transmission line was destroyed before it was completely depreciated. Assets that are not or can no longer be used for utility service, but which have not been completely depreciated, are said to be stranded. Under the nohindsight prudent investment test, the risk of stranded assets is borne by ratepayers. Once a capital expenditure was determined to be prudent and the related asset was placed into service, the utility was assured of full cost recovery.

\section{B. Sale of Property Outside the Ordinary Course OF BUSINESS AND THE TRANSALTA FORMULA}

One of the incidental powers granted to the Board of Public Utilities Commissioners in the 1915 statute was the authority to approve the sale of any utility property outside of the ordinary course of utility business. ${ }^{15}$ This power persists today, and Alberta gas and electric utilities are required to obtain Commission approval before they "sell, lease, mortgage or otherwise dispose of or encumber ... [their] property, franchises, privileges or rights, or any part of it or them" outside the ordinary course of the owner's business. ${ }^{16}$

Methodology for Managing Gas Supply Portfolios and Determining Gas Cost Recovery Rates Proceeding and Gas Rate Unbundling Proceeding (12 December 2001), 2001-110 at 10, online: EUB $<$ www.auc.ab.ca/regulatory_documents/ProceedingDocuments/2001/2001-110.pdf $>$ [EUB Decision 2001-110]

13 Ibid, citing 1999/2000 General Rate Application Phase 1 and Phase 2 (2 February 2000), 2000-1 at 46, online: EUB <www.auc.ab.ca/regulatory_documents/ProceedingDocuments/2000/2000-01.pdf>; Alberta Power Limited, Edmonton Power and TransAlta Utilities Corporation (10 December 1993), Alta PUB Decision No E93094 at 105. This test was affirmed in ATCO Gas and Pipelines Ltd v Alberta (Energy and Utilities Board), 2005 ABCA 122.

EUB Decision 2001-110, ibid at 9-10.

PUA 1915, supra note 6, s 29(g).

Gas Utilities Act, RSA 2000, c G-5, s 26(2)(d) [GUA]; Public Utilities Act, RSA 2000, c P-45, s 101(2)(d) [PUA]. 
Historically, the Commission's predecessors applied a "no harm" test to determine whether or not to approve a disposition of utility property. Under this test, the utility must show that the proposed disposition would not harm customers, "either through higher rates or by degradation of service." 17 If a proposed transaction potentially resulted in a material harm to customers, or left them worse off in either respect, the regulator would deny the application, unless the harm could be mitigated through the allocation of the proceeds of sale to ratepayers. ${ }^{18}$

If a proposed disposition passed the no harm test, the practice was then to determine the allocation of the proceeds of the sale of the property. Although the power to allocate proceeds of the sale of utility property has never been expressly provided for in any of the statutory schemes governing utility regulation in Alberta, ${ }^{19}$ the Commission's predecessors determined that they had jurisdiction to do so by virtue of their broad public interest mandate, their general supervisory power over public utilities, and their legislated authority to impose conditions on orders and authorizations made in exercise of their jurisdiction. ${ }^{20}$

Prior to 1986, the Public Utility Board's practice was to allocate the entire gain or loss arising on the disposition of the sale of utility assets to customers. This allocation was driven by the Board's general direction to set " "just and reasonable' rates" in order to ensure that utilities earned a fair return, nothing more and nothing less, as a result of windfall gains or losses on the disposition of property. ${ }^{21}$

This practice changed in 1986 in response to the Alberta Court of Appeal's decision in TransAlta Utilities Corporation v. Alberta (Public Utilities Board). ${ }^{22}$ This appeal arose in the context of the sale of utility assets from TransAlta to the City of Edmonton as a result of the expansion of the city through annexation into a distribution service area previously served by TransAlta. In TransAlta, the Court disagreed with the "general rule" previously applied by the Board that any "profit or loss ... resulting from the disposal of utility assets [outside the ordinary course of business] should accrue to ... customers." ${ }^{23}$ The Court held that customers were only entitled to be credited for the inflation adjusted present value of the depreciation allowance ${ }^{24}$ that had been previously recovered in relation to the assets by TransAlta in its rates. The rationale for this was that " $[\mathrm{t}] \mathrm{o}$ the extent ... that allowance for

TransAlta Utilities Corporation Sale of Distribution Business (5 July 2000), 2000-41 at 8, online: EUB $<$ www.auc.ab.ca/regulatory documents/ProceedingDocuments/2000/2000-41.pdf $>$ [EUB Decision 2000-41]; Utility Asset Disposition (26 November 2013), 2013-417 at para 20, online: AUC $<$ www.auc.ab.ca/regulatory_documents/ProceedingDocuments/2013/2013-417.pdf $>$ [UAD Decision]. UAD Decision, ibid; EUB Decision 2000-41, ibid at 8-9.

Stores Block, supra note 1 at paras 54-59.

EUB Decision 2000-41, supra note 17 at 8; ATCO Gas - North a Division of ATCO Gas and Pipelines Ltd - Sale of Certain Petroleum and Natural Gas Rights, Production and Gathering Assets, Storage Assets and Inventory (31 July 2001), 2001-65 at 16, online: EUB <www.auc.ab.ca/regulatory documents/ProceedingDocuments/2001/2001-65.pdf $>$.

21 TransAlta Utilities Corporation v Public Utilities Board (Alta), 1986 ABCA 64 at para 14 [TransAlta]; see the Public Utilities Board (PUB) decision in Gas Utilities Act and Public Utilities Board Act (12 October 1984), Alta PUB Decision No E84113 at 18-20 [PUB Decision E84113]. Although PUB Decision E84113 considered the GUA, an identical statement was made by the PUB in TransAlta Utilities Corp (1984) (12 October 1984), Alta PUB Decision No E84116 at 16.

TransAlta, ibid.

Ibid at paras 16-17.

A depreciation allowance allows an investor to recover the original capital investment it made in relation to its depreciable assets. The effect of a depreciation allowance is to permit an investor to charge a surcharge beyond the approved rate of return because the deemed depreciation is treated as a cost for accounting purposes. 
depreciation has been made, the original investment has already been returned to the investors. ${ }^{25}$ The Court concluded that the balance of the proceeds of sale of utility assets were for the utility shareholders, on the basis that "[s]ubject to the depreciation allowance, the proceeds must be deemed to be the present value of this portion of the rate base, and should not be assigned to revenue." 26

Based on the decision of the Court in TransAlta, the Alberta Energy and Utilities Board (EUB) applied what came to be known as the "TransAlta Formula" in several subsequent decisions. The EUB described the TransAlta Formula in EUB Decision 2000-41:

\footnotetext{
[T] he Board has interpreted the Court of Appeal's conclusion to mean that where the sale price exceeds the original cost of the assets, shareholders are entitled to net book value (in historical dollars), customers are entitled to the difference between net book value and original cost, and any appreciation in the value of the assets (i.e. the difference between original cost and the sale price) is to be shared by shareholders and customers. The amount to be shared by each is determined by multiplying the ratio of sale price/original cost to the net book value (for shareholders) and the difference between original cost and net book value (for customers). However, where the sale price does not exceed original cost, customers are entitled to all of the gain on sale. $^{27}$
}

The TransAlta Formula was used from 1986 until Stores Block.

\section{STORES BLOCK}

In August 2001, ATCO Gas sought approval for the sale of land and buildings located just outside downtown Calgary, known as the Stores Block. ATCO Gas informed the EUB that the property was no longer used and useful in the provision of gas utility services and requested that a sale to the Calgary Co-operative Association Limited be approved under section 26 of the Gas Utilities Act. ${ }^{28}$ ATCO Gas claimed that the property would provide no ongoing benefit or service to customers, that the proposed sale would result in no harm to customers, and that the sale would actually reduce customer costs by $\$ 625,000$ over ten years. ${ }^{29}$ ATCO Gas argued that the proceeds of sale should first be used to retire the remaining net book value of the property from rate base and cover any costs of disposition, and that the balance of the net proceeds of the sale should accrue to the benefit of shareholders as a gain on sale. ${ }^{30}$ Although ATCO's argument did not comply with the TransAlta Formula, ATCO argued that its entitlement to the entire proceeds of the sale was a "necessary incident of ownership" of the property, and that TransAlta could be distinguished on its facts. ${ }^{31}$

TransAlta, supra note 21 at para 44.

Ibid at para 43.

Supra note 17 at 26-27 [footnotes omitted].

GUA, supra note 16, s 26(2)(d); PUA, supra note 16, s 101(2)(d).

ATCO Gas and Pipelines Ltd - Disposition of Calgary Stores Block and Distribution of Net Proceeds

- Part 2 (21 March 2002), 2002-037, online: EUB < www.auc.ab.ca/regulatory_documents/Proceeding Documents/2002/2002-037.pdf> [EUB Decision 2002-037].

Ibid.

Ibid at 20 . 
In EUB Decision 2001-78, the EUB found that the sale satisfied the no harm test and approved it. ${ }^{32}$ However, it deferred consideration of the application and disposition of the proceeds of the sale, including any net gain on the sale, to a subsequent proceeding. ${ }^{33}$ In EUB Decision 2002-037 the EUB reaffirmed the finding of no harm and determined that it was appropriate to allocate the $\$ 6.1$ million in proceeds from the sale, including a $\$ 5.4$ million net gain, in accordance with the TransAlta Formula. ${ }^{34}$ As such, the net proceeds of the sale of the property were divided as follows:

- $\quad$ ATCO Gas was allocated an amount equal to the net book value of the property (\$225k);

- $\quad$ customers were allocated an amount equal to the accumulated depreciation on the property $(\$ 455 \mathrm{k})$; and

- $\quad$ the \$5.4 million gain on sale was divided between ATCO Gas and customers in accordance with the ratio of sale price/original cost to the net book value (for shareholders), and the difference between original cost and net book value (for customers), resulting in customers being allocated \$3.6 million, and ATCO Gas being allocated $\$ 1.8$ million. $^{35}$

ATCO Gas appealed this decision to the Alberta Court of Appeal, arguing that the EUB did not have the jurisdiction to apportion the net proceeds of sale. ${ }^{36}$ The Court of Appeal agreed with ATCO Gas and overturned the EUB's decision. ${ }^{37}$ The Court of Appeal held that although the EUB had a broad mandate under its governing legislation to protect consumers in the public interest, this statutory grant of authority was not unlimited, and was confined to powers either explicitly statutorily granted or "necessary [by] implication" to fulfill its statutory mandate. ${ }^{38}$ The Court noted that although section 15(3) of the Alberta Energy and Utilities Board Act $\mathrm{At}^{39}$ authorized the EUB to attach conditions to any order that "the Board considers necessary in the public interest," any such condition must, by implication, be necessary to protect a public interest. ${ }^{40}$

The Court of Appeal held that since the EUB had determined that no harm would result to customers from the sale, the EUB had no authority to allocate the proceeds of sale, as there was no harm to the public interest to protect against. ${ }^{41}$ On this basis, the Court of Appeal determined that the EUB's allocation of a portion of the gain on the sale of ATCO Gas'

ATCO Gas Pipelines Ltd - Disposition of Calgary Stores Block and Distribution of Net Proceeds Part 1 (24 October 2001), 2001-78, online: EUB <www.auc.ab.ca/regulatory_documents/Proceeding Documents/2001/2001-78.pdf $>$ [EUB Decision 2001-78].

Ibid at 4

Supra note 29 at $16,18,29$.

Ibid at 29.

ATCO Gas and Pipelines Ltd v Alberta (Energy and Utilities Board), 2004 ABCA 3 [SBCA].

Ibid.

Ibid at paras 49-53.

SA 1994, c A-19.5, s 10(3)(d).

SBCA, supra note 36 at para 50 .

Ibid at paras 61-63. 
property to customers in accordance with the TransAlta Formula exceeded its jurisdiction, and was confiscatory, ${ }^{42}$ as customers do not have a proprietary interest in utility assets:

Consumers of utilities pay for a service, but by such payment, do not receive a proprietary right in the assets of the utility company. Where the calculated rates represent the fee for the service provided in the relevant period of time, ratepayers do not gain equitable or legal rights to non-depreciable assets when they have paid only for the use of those assets. ${ }^{43}$

The Court of Appeal therefore directed that the entire net proceeds of the sale, less an amount equal to accumulated depreciation, be credited to ATCO Gas. ${ }^{44}$

The EUB and The City of Calgary both sought leave to appeal to the Supreme Court of Canada. ATCO Gas filed a conditional cross-appeal. The Supreme Court of Canada granted leave. The Supreme Court of Canada ruled that the EUB did not have the right to appeal its own decisions, but granted it intervener status. ${ }^{45}$

A majority of the Supreme Court of Canada ${ }^{46}$ dismissed Calgary's appeal, and concluded that the EUB had no statutory jurisdiction to allocate to ratepayers a portion of any net gain realized on the sale of utility property outside the ordinary course of business. ${ }^{47}$ The majority also allowed ATCO Gas' cross-appeal of the Alberta Court of Appeal's decision to allocate to ratepayers a portion of the sales proceeds equal to the accumulated depreciation. It also held that the Court of Appeal had erred and should have concluded that the EUB had "no jurisdiction to allocate any portion of the proceeds of sale of the property to ratepayers." In so doing, the Supreme Court ended the use of the TransAlta Formula.

Justice Bastarache based his decision on two key holdings (applying a correctness standard of review). ${ }^{49}$ First, he held that the powers of the EUB, though broad, are limited to those granted to it by its enabling statutes, and that the EUB's ability to impose conditions must be contextually interpreted in light of its main functions of fixing just and reasonable rates and protecting the integrity and dependability of the supply system. ${ }^{50}$ Second, he held that property employed by utilities in providing utility service to customers belongs solely to the utility and its shareholders, and that the regulatory compact does not transfer any property right to customers. ${ }^{51}$ Justice Bastarache also held that allowing the EUB to allocate

\footnotetext{
Ibid at para 67.

Ibid at para 64

Ibid at para 68 .

Ibid, leave to appeal to SCC refused, 30247 (29 March 2004).

Per Bastarache J (LeBel, Deschamps, and Charron JJ concurring), Binnie J dissenting (McLachlin CJC and Fish J concurring).

Stores Block, supra note 1 at para 18.

Ibid at para 34.

Ibid at para 21, citing Pushpanathan v Canada (Minister of Citizenship and Immigration), [1998] 1 SCR 982. Stores Block was decided before Dunsmuir v New Brunswick, 2008 SCC 9. It is tempting to wonder whether the Supreme Court would have applied a reasonableness standard of review if the case were before it today, on the basis that the issue involved the interpretation of the EUB's "home" statute. Stores Block, ibid at paras 7, 50 .

Ibid at para 69 .
} 
a portion of the proceeds of sale of utility property to ratepayers is contrary to the regulatory compact, and the principles of property ownership:

[T] he "regulatory compact" ... ensures that all customers have access to the utility at a fair price — nothing more. As I will further explain, it does not transfer onto the customers any property right. Under the regulatory compact, the regulated utilities are given exclusive rights to sell their services within a specific area at rates that will provide companies the opportunity to earn a fair return for their investors. In return for this right of exclusivity, utilities assume a duty to adequately and reliably serve all customers in their determined territories, and are required to have their rates and certain operations regulated.

[W]hen interpreting the broad powers of the Board, one cannot ignore this well-balanced regulatory arrangement which serves as a backdrop for contextual interpretation. The object of the statutes is to protect both the customer and the investor. The arrangement does not, however, cancel the private nature of the utility. In essence, the Board is responsible for maintaining a tariff that enhances the economic benefits to consumers and investors of the utility.

The fact that the utility is given the opportunity to make a profit on its services and a fair return on its investment in its assets should not and cannot stop the utility from benefiting from the profits which follow the sale of assets. Neither is the utility protected from losses incurred from the sale of assets ... ownership of the assets is clearly that of the utility; ownership of the asset and entitlement to profits or losses upon its realization are one and the same. ${ }^{52}$

\section{Justice Bastarache confirmed that}

[t]hrough the rates, the customers pay an amount for the regulated service that equals the cost of the service and the necessary resources. They do not by their payment implicitly purchase the asset from the utility's investors. The payment does not incorporate acquiring ownership or control of the utility's assets. The ratepayer covers the cost of using the service, not the holding cost of the assets themselves. ${ }^{53}$

On this basis, he concluded for the majority that the EUB misdirected itself when it confused "the interests of the customers in obtaining safe and efficient utility service with an interest in the underlying assets owned only by the utility," and allocated a portion of the proceeds of sale of ATCO Gas' property to ratepayers. ${ }^{54}$

It is important to note that the issues considered in the Stores Block were relatively narrow. On its facts, the Stores Block decision was limited to consideration of the jurisdiction of the Commission when considering an application under the GUA by a gas utility to dispose of assets outside the ordinary course of business. Although Justice Bastarache made

52 Ibid at paras 63-64, 67 [citations omitted] [emphasis in original].

$53 \quad$ Ibid at para 68 .

$54 \quad$ Ibid at para 69 
broad pronouncements about the nature of utility asset ownership, the decision did not deal with anything but the disposition of gas utility assets outside the ordinary course of business.

Initially the decision in Stores Block was well received by Alberta utilities which, at the time, could not foresee how the Commission would interpret and extend it.

\section{Post-Stores Block Decisions}

In a number of post-Stores Block decisions, the EUB, the AUC, and the Alberta Court of Appeal have explored the implications of the principles identified in Stores Block. This has included the principles that by paying rates for utility service customers acquire no proprietary interest in the assets used to provide that service, that utilities alone are entitled to gains on the disposition of utility property outside the ordinary course of business, and that ownership of the asset and entitlement to profits or losses on its realization are one and the same. ${ }^{55}$ Key aspects of these post-Stores Block decisions that paved the way for the UAD Decision are summarized below.

\section{A. CARBON ${ }^{56}$}

In Carbon, the EUB and the Alberta Court of Appeal considered the meaning of the phrase "used or required to be used to provide service" from section 37 of the GUA, in order to determine when assets should be in a gas utility's rate base. ${ }^{57}$

For decades, ATCO Gas had owned and operated a natural gas storage facility (Carbon Storage). Carbon Storage had initially been used in connection with ATCO Gas' regulated gas distribution business as well as for revenue generation (which was passed through to customers as a reduction to ATCO Gas' revenue requirement) by leasing excess storage capacity to third parties. ${ }^{58}$ However, following the restructuring of the energy industry in Alberta that created a competitive unregulated market for retail electricity and natural gas, ATCO Gas sold its retail function to Direct Energy Regulated Services. ${ }^{59}$ This meant ATCO Gas no longer needed Carbon Storage in order to provide regulated gas utility service. ATCO Gas continued to lease storage to third parties, however.

ATCO Gas took the position that Carbon Storage was no longer "used or required to be used to provide service to the public" and was thus not properly part of its rate base under section 37 of the GUA. ${ }^{60}$ In EUB Decision 2007-005, the EUB concluded that Carbon Storage continued to be "used or required to be used to provide service" because it had

An extensive summary and canvassing of jurisprudential and Commission treatment and consideration of the Stores Block decision is set out in of the UAD Decision, supra note 17 at 15-32, discussed below. ATCO Gas South - Carbon Facilities Part 1 Module - Jurisdiction (2005/2006 Carbon Storage Plan) (5 February 2007), 2007-05, online: <www.auc.ab.ca/regulatory documents/ProceedingDocuments/ 2007/2007-005.pdf> [EUB Decision 2007-05]; ATCO Gas and Pipelines Ltd v Alberta (Energy And Utilities Board), 2008 ABCA 200 [Carbon].

Carbon, ibid at para 1; GUA, supra note 16, s 37.

Carbon, ibid at para 4 .

Ibid at para 6 .

Ibid at para 9 . 
played a unique historical role as an operational part of ATCO's gas distribution system, and continued to generate revenue by leasing excess storage capacity to third parties. ${ }^{61}$

The Alberta Court of Appeal overturned the decision on the basis that EUB had wrongly included Carbon Storage in rate base when its only remaining function was to generate alternate, non-utility revenue. The Court held that the "used or required to be used to provide a service" test under section 37 of the GUA was intended to capture "assets that are presently used, are reasonably used, and are likely to be used in the future to provide [utility] services. ${ }^{\prime 62}$ Past or historical use of assets should not permit asset inclusion in rate base unless such assets continue to be used to provide a utility service, in an operational sense. ${ }^{63}$ The Court reasoned that, just because an asset was previously properly included in rate base, does not mean that such asset will be in rate base forever. ${ }^{64}$ The Court stated that to find otherwise would be inconsistent with Stores Block:

The Act does not contain any provision or presumption that once an asset is part of the rate base, it is forever a part of the rate base regardless of its function. The concept of assets becoming "dedicated to service" and so remaining in the rate base forever is inconsistent with the decision in Stores Block (at para. 69). Such an approach would fetter the discretion of the Board in dealing with changing circumstances. Previous inclusion in the rate base is not determinative or necessarily important...: "That was then, this is now." 65

The Court of Appeal also noted that under the gas utility regulatory regime, revenue generation cannot reasonably be regarded as a "utility service" given that the delivery of gas is the utility service according to section $28(\mathrm{e})$ of the GUA. ${ }^{66}$ Building on Stores Block, the Court of Appeal concluded that, just as utility customers do not obtain an ownership interest in assets of a utility, they also have no interest in or right to "the profits, unregulated revenues, or unregulated businesses of the utility." ${ }^{, 97}$

\section{B. HARVEST HILLS ${ }^{68}$}

In Harvest Hills, the EUB and the Alberta Court of Appeal considered the appropriate treatment of property which, although no longer required for utility service, remained in rate base and revisited what constitutes harm under the "no harm" test.

In EUB Decision 2007-101, the EUB considered an application by ATCO Gas to subdivide certain lands in Calgary that were included in its rate base (the Harvest Hills Property). Part of the Harvest Hills Property had been used to construct a regulating station used for utility service; however, another part of the land was vacant and had never been

EUB Decision 2007-05, supra note 56 at 26-27.

Carbon, supra note 56 at para 23.

Ibid at paras $23,25$.

Ibid at para 29.

Ibid [citations omitted].

GUA, supra note 16 , s $28(\mathrm{e})$.

Ibid at para 30.

ATCO Gas - Disposition of Land in the Harvest Hills Area (11 December 2007), 2007-101, online: EUB < www.auc.ab.ca/regulatory_documents/ProceedingDocuments/2007/2007-101.pdf $>$ [EUB Decision 2007-101]; ATCO Gas and Pipelines Ltd v Alberta (Energy and Utilities Board), 2009 ABCA 171 [Harvest Hills]. 
used for utility purposes. ${ }^{69}$ ATCO Gas proposed to subdivide the Harvest Hills Property, retain the portion used for utility service, and sell the remaining portion (Surplus Lands) to a third party. ${ }^{70}$ Relying on Stores Block, ATCO Gas argued that its shareholder was entitled to the net proceeds of the sale. ${ }^{71}$ Although ATCO Gas did not anticipate that the Surplus Lands would be required in the future for utility service, it indicated that within five years of the proposed disposition, it would need to purchase land approximately five kilometers from the Harvest Hills Property for utility use (Future Development). ${ }^{72}$

The EUB concluded that the sale did not meet the no harm test, because the sale of the Surplus Lands followed by the Future Development would cause financial harm to customers. ${ }^{73}$ Relying on the Stores Block decision, ${ }^{74}$ the EUB approved the sale, but directed that the net proceeds from the disposition of the Harvest Hills Property be used to offset the construction costs of the Future Development. ${ }^{75}$ The Court of Appeal allowed ATCO Gas' appeal, concluding that the EUB erred in its application of the no harm test. ${ }^{76}$ The Court stated that the harm must be related to the transaction in question, and that costs incurred independently of the transaction (the cost of the Future Development) did not amount to harm. ${ }^{77}$ In the absence of harm, the EUB did not have the right to impose financial conditions on the sale (which the Court found to be an improper subsidy of ratepayers by the utility shareholder). ${ }^{78}$

The Court of Appeal also found that although the Surplus Lands portion of the Harvest Hills Property was never used to provide utility services it was not necessarily improperly included in rate base. ${ }^{79}$ However, it did hold that once ATCO Gas determined that the Surplus Lands were not required to provide utility service, they should have been removed from rate base as they were no longer "used or required to be used" as required by section 37 of the GUA. ${ }^{80}$ On its face, the Court of Appeal's reasoning appears sound, given the absence of any real nexus between the sale of the Surplus Lands and the Future Development.

Harvest Hills, ibid at paras 2-4.

Ibid.

Ibid at para 4 .

Ibid at para 8 .

EUB Decision 2007-101, supra note 68 at 7.

Stores Block, supra note 1 at para 77 :

The Board has other options within its jurisdiction which do not involve the appropriation of

the sale proceeds, the most obvious one being to refuse to approve a sale that will, in the

Board's view, affect the quality and/or quantity of the service offered by the utility or create additional operating costs for the future. This is not to say that the Board can never attach a condition to the approval of sale. For example, the Board could approve the sale of the assets on the condition that the utility company gives undertakings regarding the replacement of the assets and their profitability. It could also require as a condition that the utility reinvest part of the sale proceeds back into the company in order to maintain a modern operating system that achieves the optimal growth of the system.

Harvest Hills, supra note 68 at para 11 .

Ibid at para 32 .

Ibid.

Ibid.

Ibid at para 14.

Ibid. 


\section{SALt CAVERNS ${ }^{81}$}

In Salt Caverns, the issue of when regulatory approval under section 26 of the GUA is required to remove property and assets from rate base was considered by the EUB and the Court of Appeal.

In 2007, ATCO Gas filed a general rate application with the EUB. In that application it excluded certain underground gas storage assets (the Salt Cavern Assets) from its rate base. ${ }^{82}$ In its application, ATCO Gas informed the EUB that the assets were no longer being used for utility service. ${ }^{83}$ The EUB directed ATCO Gas to include the Salt Cavern Assets in its application. ${ }^{84}$ The EUB stated that removal from rate base constituted a disposition that required advance EUB approval under paragraph $26(2)(\mathrm{d})$ of the $G U A{ }^{85}$

ATCO Gas successfully appealed the ruling. The Court of Appeal concluded that the EUB did not have the jurisdiction to include assets that no longer had any operational use in rate base.$^{86}$ It further held that the unilateral withdrawal from utility service of an asset that is no longer used or required to be used is not a "disposition" within the meaning of subsection 26(2) of the GUA.$^{87}$ The Court found that ending a particular use of an asset without any sale, transfer or relinquishment of the asset to a third party does not require regulatory approval, ${ }^{88}$ and it affirmed that section 26 of the GUA does not apply to non-utility assets. ${ }^{89}$ The Court did say that a determination of whether an asset was used or required to be used for utility service was within the EUB's jurisdiction. ${ }^{90}$

The Court of Appeal's reasoning is compelling, and this decision is noteworthy for its relatively narrow interpretation of "disposition."

\section{Utility ASSET Disposition DECISIONS}

\section{A. The UAD DeCISION ${ }^{91}$}

After Stores Block, the Commission initiated the UAD proceeding in order to develop a comprehensive understanding of the potential implications of Stores Block and then apply that understanding in a consistent manner in future decisions. ${ }^{92}$ Although the proceeding was initiated in 2008, it was suspended until 17 October 2012 to allow the hearing of the appeals described above.

ATCO Gas and Pipelines Ltd v Alberta (Utilities Commission), 2009 ABCA 246 [Salt Caverns]. Ibid at para 3 .

Ibid.

Ibid.

Ibid at para 4 .

Ibid at para 14

Ibid at paras 51-56; GUA, supra note 16, s 26(2).

Ibid at para 56 .

Ibid at para 55.

Ibid at paras 28-30, 54.

UAD Decision, supra note 17.

Ibid (Notice of Commission Initiated Proceeding), online: AUC <www.auc.ab.ca/regulatory documents/ProceedingDocuments/2008/1566373.pdf $>$. 
In the first part of the UAD Decision, the Commission summarized the Stores Block decision, as well as relevant decisions considering Stores Block from the Commission, Alberta Court of Appeal, and other jurisdictions in Canada. ${ }^{93}$ It then provided a list of 19 principles based on these decisions. ${ }^{94}$

In the second part of the UAD Decision, the Commission made several findings based on the issues in the proceeding issues list and the evidence provided in response by the Alberta Utilities and other interested parties, including those representing customers. ${ }^{95}$ They can be summarized as follows:

- The utility asset ownership principles in Stores Block ${ }^{96}$ considered in the context of the disposition of gas utility assets under section 26 of the GUA apply equally to the disposition of electric utility assets outside of the ordinary course of business under section 101(2) of the PUA. ${ }^{97}$

- The utility asset ownership principles set out in Stores Block apply to the disposition of all utility assets, regardless of whether the property is disposed of inside or outside the ordinary course of business. ${ }^{98}$ The Commission stated that any other conclusion would mean that customers must have acquired some sort of property interest in assets disposed of in the ordinary course of business. ${ }^{99}$

- Assets that are not "used or required to be used" for utility service may not be included in rate base. ${ }^{100}$ This applies to both gas ${ }^{101}$ and electric utility assets. ${ }^{102}$

- The current depreciation methodology used in Alberta, which calculates depreciation using mass property accounts, effectively retires assets from rate base in the ordinary course of business when they are "no longer used or required to be

UAD Decision, ibid at paras 19-26.

Ibid at para 102 .

Ibid at paras 263-336. The "Alberta Utilities" are defined in the UAD Decision as: ATCO Utilities, AltaLink Management Ltd, AltaGas Utilities Inc, ENMAX Power Corporation, EPCOR Utilities Inc, and FortisAlberta Inc (ibid at para 8).

For example, that utility assets are the property of the utility company and its shareholders and that customers of utility companies do not purchase a property interest in those assets when they purchase utility services: Stores Block, supra note 1 at para 68 (cited in the UAD Decision, ibid at para 269).

UAD Decision, ibid at para 264.

Ibid at paras 263, 271. The Commission also reasoned that given that the Commission's jurisdiction is to set just and reasonable rates for utility assets, regardless if they are outside of the ordinary course of business, it would be inconsistent with this jurisdiction to find that the utility asset ownership principles were limited to assets disposed of outside of the ordinary course of business (ibid at para 268).

Ibid at para 271.

Ibid at paras 273-84.

Ibid at para 274 .

The utilities argued that the Electric Utilities Act, SA 2003, c E-5.1 [EUA] requires recovery of prudently incurred costs for assets such that these assets are to remain in rate base until they have been fully paid for by customers, regardless if the asset is used or required to be used. The Commission held that this position was in conflict with the property ownership principles in Stores Block and that while the terms "rate base" and "used or required to be used to provide utility service" are not employed in the EUA, the same concepts apply since the EUA defines an electric utility as a transmission or electric distribution system that is "used" to provide utility service or "necessary" to provide the service (UAD Decision, ibid at paras 281-83). 
used to provide service." ${ }^{103}$ This methodology appears to have been informed by the same principles in Stores Block and Alberta Court of Appeal cases. ${ }^{104}$

- The amortization of reserve differences (AORD) methodology used by utilities in Alberta (pursuant to which customers are charged or refunded, on a prospective basis, for depreciation rate adjustments that result from an over- or under-recovery of depreciation expense in prior years) is consistent with the Stores Block and Alberta Court of Appeal principles. This is because the AORD methodology ensures "that customers pay no more and no less, and the utilities recover no more and no less, than the cost of assets used to provide utility service over the period of time in which the assets provided utility service." 105

- $\quad$ Responsibility for stranded asset risk, namely the risk of not being able to recover the remaining value of assets that cease to be used or required for use in utility service, and therefore must be removed from rate base, depends on whether the retirement of existing assets is "ordinary" or "extraordinary." For ordinary retirements, under-recovery or over-recovery of capital investment are the responsibility of customers under the AORD methodology. For extraordinary retirements, including "assets disposed of outside of the ordinary course of business or moved to a non-utility account," under-recovery or over-recovery of capital investments is for the account of the utility. ${ }^{106}$

- The retirement provisions in the 1963 Uniform System of Accounting for Natural Gas Utilities ${ }^{107}$ and the Commission's Uniform System of Accounts for electric utilities ${ }^{108}$ are consistent with the principles from Stores Block and the Alberta Court of Appeal, as are the definitions of "ordinary" retirement and "extraordinary" retirement from the USANGU: ${ }^{109}$

- "Ordinary retirements result from causes reasonably assumed to have been contemplated in prior depreciation provisions, and normally may be expected to occur when plant reaches the end of its expected life." 110

- "Extraordinary retirements result from causes not reasonably assumed to have been anticipated or contemplated in prior depreciation or amortization provisions." "11

- Extraordinary retirements include "obsolete property, property to be abandoned, overdeveloped property," facilities that go beyond what is necessary to fulfill future 
needs, "property used for non-utility purposes, property that should be removed because of circumstances including unusual casualties (fire, storm, flood, etc.), sudden and complete obsolescence, or un-expected and permanent shutdown of an entire operating assembly or plant."112

- Utility assets "used or required to be used" are those used in an "operational sense," meaning assets "that are presently used, reasonably used or likely to be used in the future to provide utility services." 113

- Surplus land ${ }^{114}$ and depreciable assets which should be treated as extraordinary retirements must be removed from rate base because they are no longer used or required to be used for utility service. ${ }^{115}$

In summary, the Commission held that the utility asset ownership principles of Stores Block applied not only to the disposition of gas utility assets outside the ordinary course of business (which were the facts considered in Stores Block) but also to all electric utility assets disposed of outside of the ordinary course of business and all electric and gas utility assets disposed of or retired in the ordinary course of business. The principal conclusion of the Commission is summarized in the UAD Decision:

The courts have now clarified the matter, stating that all proceeds and losses on all utility assets are for the account of the shareholders, as the sole owners of the utility assets. As property owner, the utility can expect compensation from customers in respect of its asset only for so long as those assets are used (as determined on a reasonable basis) to provide service to customers. Whatever the perspective, the property law principles of ownership must be applied symmetrically to all utility assets. ${ }^{116}$

In effect, for gas and electric utilities in Alberta, the Commission held that stranded assets, being assets that are not fully depreciated but are no longer capable of being used, must be removed from rate base, and that extraordinary retirements of such assets, are to the account of utilities, not to the account of customers. This represented a tectonic shift in the regulatory landscape and took the Commission out of the mainstream of utility regulation in Canada. For the reasons addressed subsequently, the UAD Decision arguably significantly stretched and distorted the principle holding in Stores Block in a manner that had consequences that were likely not anticipated at the time Stores Block was decided.

\section{B. THE UAD APPEAL ${ }^{117}$}

Not surprisingly, the Alberta gas and electric utilities appealed the UAD Decision. The gas and electric utilities advanced slightly different arguments based on differences in the gas and electric utility legislation. ${ }^{118}$ However, both the gas and electric utilities' arguments shared the same foundational premise - that under their applicable legislative scheme, once 
costs had been deemed prudent, utilities were assured of an opportunity to recover those costs. The Court of Appeal rejected this argument, finding that the Commission's decision, which it called a "generic policy decision," 119 was reasonable.

On this basis, applying the reasonableness standard of review, the Court of Appeal rejected the appeals, finding that Stores Block should not and could not be confined to its facts:

It might have been possible at one time to confine the scope of Stores Block so as to be less intrusive on the Regulator's discretion, perhaps by restricting its application only to approval of asset sales under s 26 and not to the ratemaking function. However, the law as it has developed in Alberta since 2006 has not done that. Rather than approaching Stores Block in a restrictive manner, this Court has applied the principles set out in that case more broadly.

It has also been suggested that the approach in Stores Block should be confined to non-depreciable assets only. In my view, the decision does not support this interpretation. The distinction between depreciable and non-depreciable assets was never made in Stores Block, where the asset being disposed of consisted of both land and buildings. Indeed, at para 69 of his decision Bastarache J speaks of utilities absorbing "losses and gains, increases and decreases in the value of assets" based on economic conditions and "occasional unexpected technical difficulties". It is difficult to reconcile this language with the idea that the court was referring only to non-depreciable assets, which would rarely be sold at a loss and would not often be subject to "unexpected technical difficulties". Such an interpretation could lead to a lopsided and arguably unreasonable result; utilities would be entitled to the benefit of a gain from a sale of non-depreciable assets, but would not be exposed to a loss on depreciable property. Ratepayers on the other hand would likely only be exposed to losses. 120

The Court of Appeal held that the Commission's approach, in light of Stores Block, was reasonable and in line with its core ratemaking function. ${ }^{121}$ The Court also concluded that the Commission's approach to the return of capital investment through the management of depreciation accounts and the distinction it made between ordinary and extraordinary retirements in that respect was reasonable. ${ }^{122}$

The Court noted that the Commission did not fetter its discretion to handle future cases, recognizing "its ability to adjust for depreciation and amortization expenses of assets removed from service for unanticipated causes through its [AORD] process, ... retain[ing] the flexibility to fulfill its mandate on a case by case basis." ${ }^{123}$ As discussed below, in application, the Commission's approach was not particularly flexible, and resulted in troublesome outcomes.

$\begin{array}{ll}119 & \text { Ibid at para } 96 . \\ 120 & \text { Ibid at paras 74-75. } \\ 121 & \text { Ibid at paras } 147,164-65 . \\ 122 & \text { Ibid. } \\ 123 & \text { Ibid at para } 168 .\end{array}$


In concluding her decision on the UAD appeals, Justice Paperny noted:

\begin{abstract}
The legislature has entrusted the Commission with a policy-laden role, which includes a strong public interest mandate: see, for example, ss 16(1) and 17(1) of the Alberta Utilities Commission Act. Its mandate includes the creation of a balanced and predictable application of principles to the relationship between revenues, expenses and assets (both depreciable and non-depreciable) of utilities on the one hand, and the reasonable expectations of the ratepayers who receive and pay for services on the other. The treatment of stranded assets is, at its foundation, a policy issue informed by public interest considerations. The Commission's policy choice, as expressed in the UAD decision, is a legitimate and defensible one, and well within its legislated power. $^{124}$
\end{abstract}

Leave to appeal to the Supreme Court of Canada was denied. ${ }^{125}$

We disagree with the Court of Appeal's reasoning. Our view is that the UAD Decision is an unreasonable extension of the principles set out in Stores Block. Notably, as discussed below, the interpretation of Stores Block as requiring utilities to bear stranded asset risk has not been adopted elsewhere in Canada. It is tempting to wonder what the outcome would have been had the Court of Appeal applied the correctness standard of review or if the Supreme Court of Canada had applied the reasonableness standard in Stores Block. It is difficult to identify any relevant distinguishing characteristics between the two appeals that would justify different standards of review. Both dealt with the interpretation of provisions of the Commission's home statutes related to its core ratemaking function. However, Stores Block was decided before Dunsmuir, while the UAD Decision appeal was decided after Dunsmuir, resulting in the application of different standards of review in each decision. ${ }^{126}$

The Court of Appeal's approach to the issue may also have been coloured by its elevation of Commission decisions to the level of policy, with all of the baggage that accompanies that term, including the principle that true policy decisions made by governmental bodies are immune from challenge. ${ }^{127}$

Finally, it is noteworthy that the Court of Appeal itself appears to have been troubled by the conclusion to which the applicable standard of review and the interpretation of the jurisprudence had led it. As Justice Paperny wrote:

\footnotetext{
Absent the pronouncements in Stores Block, the Commission would likely have greater flexibility on the issue of who bears the undepreciated cost of assets rendered useless as the result of extraordinary events. There would have been a number of potential policy choices to achieve a just result.
}

\footnotetext{
$124 \quad$ Ibid at para 171.

125 Ibid, leave to appeal to SCC refused, 36728 (21 April 2016).

126 As most readers will know, the evolution of standards of review has received its own comprehensive treatment in the literature. A discussion of such evolution is well beyond the scope of this article.

127 UAD Appeal, supra note 117 at paras 171-72, cited in Gitxaala Nation $v$ Canada, 2016 FCA 187 at para 150; Re: Sound v Canadian Association of Broadcasters, 2017 FCA 138 at para 49.
} 
But Stores Block has been interpreted in Alberta as preventing such distribution. In the absence of Stores Block and the subsequent jurisprudence from this Court, other policy choices would have been open to the regulator. Although it would be tempting to confine the application of these decisions only to gas utilities, (to minimize what I consider to be deleterious effects on the regulation of utilities in Alberta), the legal principles in Stores Block remain good law. As such, the distinction the electric utilities wish to make is far less compelling. The Commission's decision, having regard to its legislation and the law of this province as set down by the Supreme Court and this Court, is reasonable. ${ }^{128}$

While Justice Paperny felt compelled to uphold the Commission's UAD Decision, it is apparent she was also uneasy with its "deleterious effects" in relation to the future ability of the Commission to achieve a "just result" in relation to the allocation of stranded asset risks, ${ }^{129}$ suggesting (perhaps with some degree of prophecy, in light of recent developments that are discussed further below) the need for a legislative solution to the problem:

The Commission, and this Court, are bound by Stores Block and the subsequent decisions from this Court. Only legislative amendment, reconsideration, or a reversal of Stores Block by the Supreme Court of Canada can change that. ${ }^{130}$

\section{Post-UAD Commission Decisions}

Since the UAD Decision and Appeal, the issue of stranded assets has been considered in several Commission decisions. The most noteworthy, in terms of understanding the Commission's approach to these assets, are the Slave Lake Fires Decision, ${ }^{131}$ the Southern Alberta Floods Decision, ${ }^{132}$ and the decisions regarding EPCOR Distribution and Transmission Inc.'s (EPCOR) Advanced Meter Infrastructure (AMI) project.

\section{A. Slave Lake Fires Decision}

In 2011, wildfires swept across the Slave Lake region, damaging and destroying electric distribution assets of ATCO Electric Ltd. (ATCO Electric). Assets with a remaining undepreciated cost of approximately $\$ 400,000$ were destroyed. ${ }^{133}$ ATCO Electric sought to recover this undepreciated capital cost, as well as removal and replacement costs. Historically, such costs would have been recovered through ATCO Electric's Reserve for Injuries and Damages (RID) account. This would have kept the cost of the destroyed assets in ATCO Electric's rates until the remaining depreciation expense was recovered. ${ }^{134}$ The RID account was approved by the Commission in EUB Decision 2007-010 as a replacement for

\footnotetext{
128 Ibid at paras $160-61$.

Ibid.

Ibid at para 76 .

ATCO Electric Ltd - 2012 Distribution Deferral Accounts and Annual Filing for Adjustment Balances (29 October 2014), 2014-297, online: AUC <www.auc.ab.ca/regulatory_documents/Proceeding Documents/2014/2014-297.pdf $>$ [Slave Lake Fires Decision] (this decision was released after the UAD Decision, supra note 17, but prior to the Court of Appeal's decision in the UAD Appeal, supra note 117).

ATCO Gas and Pipelines Ltd - Z Factor Application for Recovery of 2013 Southern Alberta Flood Costs (16 March 2016), 2738-D01-2016, online: AUC <www.auc.ab.ca/regulatory_documents/ ProceedingDocuments/2016/2738-D01-2016.pdf $>$ [Southern Alberta Floods Decision]. Slave Lake Fires Decision, supra note 131 at para 23. Ibid at para 75 .
} 
third party transmission and distribution line insurance, which was determined to be uneconomical. $^{135}$

ATCO Electric argued that the destruction of assets by fire was not an "extraordinary retirement." ${ }^{\prime 136}$ In the alternative, ATCO Electric argued that it was entitled to recover all of its prudently incurred costs under the express terms of the $E U A .{ }^{137}$ The Commission disposed of this alternative argument with reference to the principles set out in the UAD Decision. ${ }^{138}$

In considering whether destruction by fire constituted an "extraordinary retirement," the Commission reiterated its finding from the UAD Decision that the mass accounts depreciation method complied with the principles in Stores Block. It rejected ATCO Electric's suggestion that, in the UAD Decision, the Commission had endorsed a practice of recovering the costs of all retired assets through depreciation, regardless of the cause of the retirement. The Commission explained the depreciation methodology is only consistent with the principles in Stores Block for "ordinary retirements" not "extraordinary retirements":

\footnotetext{
The UAD decision recognized the concepts underlying the currently-used depreciation methods as being consistent with the Stores Block principles because they are intended to recover the costs of assets used in utility service over their service lives in ordinary circumstances, recognizing that retirements outside of the relevant scope of considered retirement events, regardless of the effect on depreciation parameters, would be classified as extraordinary retirements and, in accordance with the Stores Block principles, would be for the shareholder's account. ${ }^{139}$
}

The Commission then clarified its test for determining when a retirement was extraordinary:

In the Commission's view it is the characteristics of the event that are relevant to the determination of whether the event had been contemplated or anticipated by a prior depreciation study. If the characteristics of the Slave Lake fires event are sufficiently different to distinguish the Slave Lake fires from the events considered in the previous depreciation study such that the characteristics of the Slave Lake fires cannot be said to have been reasonably contemplated or anticipated in the determination of the depreciation parameters in that study, then the Commission would consider the event to give rise to an extraordinary retirement and the $\$ 400,000$ notional net book value of the destroyed assets would be for the account of the shareholders. ${ }^{140}$

The Commission reviewed the history of fires and natural disasters of the prior ten years that had been included in ATCO Electric's latest depreciation study. Based on this review it held that the characteristics of the Slave Lake fires that destroyed ATCO Electric's assets were sufficiently different from the characteristics of these past events, as well as the type of events that the Commission considered when it approved ATCO Electric's RID account,

ATCO Electric Ltd - 2007-2008 General Tariff Application — Phase I (22 September 2007), 2007-071, online: EUB $<$ www.auc.ab.ca/regulatory documents/ProceedingDocuments/2007/2007-071.pdf $>$ [EUB Decision 2007-071].

$136 \quad$ Slave Lake Fires Decision, supra note 131 at para 31.

137 EUA, supra note 102; Slave Lake Fires Decision, ibid at para 50.

$138 \quad$ Slave Lake Fires Decision, ibid at para 52.

$139 \quad$ Ibid at para 66

140 Ibid [emphasis added]. 
to give rise to an extraordinary retirement. ${ }^{141}$ The Commission provided no further reasoning for why the Slave Lake fires were characteristically different, but it appears the fact that the replacement costs for the Slave Lake fires (\$23.2 million) were significantly higher than prior fire-related losses carried significant weight in its decision. ${ }^{142}$ ATCO Electric was required to remove the destroyed assets from rate base, and it was not permitted to recover the remaining undepreciated capital cost (or the return it would have earned on the assets).

ATCO Electric subsequently sought approval to reinstitute third party line insurance. ${ }^{143}$ The Commission denied ATCO Electric's request, finding that one of the consequences of the principles from Stores Block is that utility customers do not, and cannot, possess an insurable interest in utility assets - it would be contrary to the symmetric application of the common law principles in Stores Block. ${ }^{144}$ This decision is troubling. In our view, the proper question is not whether ratepayers have an insurable interest in utility assets. The proper question is whether insurance premiums are a reasonable and prudent cost of providing utility service. The problem with, and inconsistency in, the Commission's reasoning is highlighted if one considers, as an example, utility vehicles. By the Commission's logic, because ratepayers do not have an insurable interest in a utility's vehicles, the cost of insuring a utility's fleet of vehicles (utility assets) should not be a recoverable cost. However, no one challenges that such costs are reasonable and prudently incurred for utility operations; the cost of insuring a utility's fleet is routinely approved for inclusion in the utility's revenue requirement. There is no principled reason that line insurance should be treated any differently.

\section{B. SOUThern Alberta Floods Decision}

In 2013, southern Alberta experienced extensive flooding. ATCO Gas applied to the Commission to recover costs associated with damage caused by the flooding. The Commission allowed the application in part. ${ }^{145}$ Notably, unlike the Slave Lake Fires Decision, the Commission concluded that the retirement of assets that had been destroyed by the flooding was not an extraordinary retirement. ${ }^{146}$

\section{Ibid at para 69}

In EUB Decision 2007-071, the Commission determined that ATCO Electric no longer had to purchase transmission and distribution line insurance, as claims would be recovered through the RID account (supra note 135 at 114). This decision was made on the basis of evidence showing that customers would have saved $\$ 924,000$ a year based on the cost of premiums and an average annual claim of $\$ 922,000$ over a period of eight years, and on the testimony of ATCO Electric witnesses that the largest claim experienced was a 1998 fire claim for $\$ 3.8$ million (Slave Lake Fires Decision, ibid at paras 76, 77). For the Slave Lake Fires Decision, the Commission calculated the average value of claims from 2002 to 2012 , excluding the Slave Lake Fires, and found it to be approximately $\$ 800,000$. The Commission concluded that the replacement costs of the assets destroyed in the Slave Lake Fires Decision were significantly higher than the prior losses that were recovered by the company through the RID account (ibid at para 77). The Commission does not explicitly state that this was the reason for finding that the destroyed fire assets were an extraordinary retirement, however, they appear to confirm this was the reason when distinguishing the Slave Lakes Fire Decision in the Southern Alberta Floods Decision (supra note 132 at para 93), which is considered below.

ATCO Electric Ltd - 2015-2017 Transmission General Tariff Application (22 August 2016), 20272D01-2016 at para 1250, online: AUC <www.auc.ab.ca/regulatory_documents/ProceedingDocuments/ 2016/20272-D01-2016.pdf>.

Ibid at para 1261 .

Southern Alberta Floods Decision, supra note 132 at para 1. Ibid at para 93 . 
In reaching this conclusion, the Commission found that ATCO Gas had included events of a similar nature in its past depreciation studies (a flood in 2005 and a tornado in 1987) and concluded that the 2013 floods had therefore been contemplated or anticipated by ATCO Gas' prior depreciation study. ${ }^{147}$ The Commission was also persuaded by the evidence of ATCO Gas' expert who had prepared its most recent depreciation study in 2009, and opined that if the 2013 flood had been included in the study in 2009, it would have had an almost indistinguishable effect on the depreciation curves. ${ }^{148}$

In the decision, the Commission explained why the destruction of assets by the Slave Lake fire was an extraordinary retirement but the destruction of assets by flooding in 2013 was not:

In the Slave Lake decision, the Commission reviewed the history of losses experienced by ATCO Electric over a 10-year period and determined that the nature of these past losses, which generally involved costs in the range of $\$ 1$ million to $\$ 2$ million, were sufficiently different from the Slave Lake region fire which required replacement costs of assets of $\$ 23.7$ million. In this proceeding, the Commission finds that the characteristics of the 2013 flood event are of a similar nature to the 2005 flood event that was incorporated in the 2009 depreciation study. Relying on this finding of fact, the Commission concludes that the 2013 flood does not give rise to an extraordinary retirement of the destroyed assets and therefore the undepreciated net book value of $\$ 496,747$ will continue to be recovered from ratepayers. ${ }^{149}$

The Commission concluded the Southern Alberta Floods Decision by addressing an argument of the Utilities Consumer Advocate (UCA) that ATCO Gas could not insist that the flood was an "unforeseen" event for the purposes of recovering cleanup costs and costs associated with damaged facilities, while at the same time arguing that the destruction of facilities was an "ordinary retirement." 150 The Commission explained that there was no inconsistency:

A depreciation study is developed to predict retirements of a group of assets over their life on the basis of past retirement events. That past events have been incorporated into depreciation studies does not negate the impact of the actual event on the operations of the company. While a storm may not be an unusual event, the impact of a particular event could very well be unforeseen and if that impact is sufficiently material, a $\mathrm{Z}$ factor may be warranted. ${ }^{151}$

\section{AMI Meter Decisions}

1. AUC DECISION 3100-D01-2015

Advanced meters are "smart meters" that transmit power usage data from a power meter remotely to a utility, removing the need for a meter reader to visit a home or business. They are typically also able to handle bi-directional flows and to record when electricity was used.

\footnotetext{
$147 \quad$ Ibid.

$148 \quad$ Ibid at paras $80,91$.

$149 \quad$ Ibid at para 93.

150 Ibid at para 87 (the tariff mechanism under which ATCO Gas claimed recovery was referred to as a Z factor. Eligible costs had to be material, caused by an event outside management's control, and prudently incurred.). 
This allows the utility to apply rates that are higher during periods of high demand and lower during periods of low demand. Bi-directional meters allow customers with on-site generation (such as solar panels) to receive a credit for excess generation that is injected onto the distribution system.

EPCOR proposed an AMI project where it would install new smart meters across its distribution system. ${ }^{152}$ This would require EPCOR to replace approximately 365,000 existing meters, the ages of which varied from almost fully depreciated to new. The Commission determined that the replacement of the existing meters would be an "extraordinary retirement," and that EPCOR would not be able to recover the remaining undepreciated capital cost of the replaced meters, which was estimated to be between $\$ 10$ and $\$ 12$ million. ${ }^{153}$ In reaching this conclusion, the Commission relied on the reference to a "sudden and complete obsolescence" from the definition of an "extraordinary retirement" in paragraph 327 of the UAD Decision. ${ }^{154}$

EPCOR argued that it did "not consider ... the existing meters [to be] obsolete because they still [operated and remained] capable of operating into the foreseeable future to provide safe and reliable utility service." 155 The utility also argued that the main driver behind replacing the existing meters was to "reduce the overall costs to customers." to conclude that the retirement of these assets is extraordinary would encourage the utility to avoid these kinds of projects. ${ }^{157}$

In finding that the retirement of the existing meters was extraordinary, the Commission relied again on the fundamental corporate and property law principles expressed in Stores Block and the test for an "extraordinary retirement" outlined in paragraph 66 of the Slave Lake Fires Decision. ${ }^{158}$ The Commission found that the existing meters would no longer be used or required for use in utility service and that it was not reasonable to conclude that the retirement was "anticipated or contemplated" in a prior depreciation study. ${ }^{159}$ In reaching the latter conclusion, the Commission relied on the fact that EPCOR's depreciation study only accounted for the retirement of these assets in 20 years, not the three-year period that EPCOR was proposing. ${ }^{160}$ The Commission did not directly address EPCOR's argument that a finding of "extraordinary retirement" creates a disincentive for EPCOR to pursue such projects.

EPCOR Distribution \& Transmission Inc - 2013 PBR Capital Tracker True-up and 2014-2015 PBR Capital Tracker Forecast (25 January 2015), 3100-D01-2015 at paras 652-56, online: AUC < www.auc. ab.ca/regulatory documents/ProceedingDocuments/2015/3100-D01-2015.pdf $>$ [AUC Decision 3100D01-2015]. 


\section{AUC DECISION 20407-D01-2016}

EPCOR decided to proceed with the AMI program notwithstanding the Commission's determination that it would result in the extraordinary retirement of the existing meters. EPCOR was subject to a five-year performance-based regulation (PBR) term at the time. ${ }^{161}$ The Commission rejected EPCOR's request to change its depreciation rates to accelerate the depreciation of the old meters. ${ }^{162}$ However, EPCOR was able to continue to depreciate the replaced meters until the end of the PBR term. ${ }^{163}$ It was also able to retain the cost savings associated with the new meters (reduced meter reading and associated labour costs, for example) until the end of the PBR term. ${ }^{164}$

\section{AUC DECISION 22394-D01-2018}

In 2016, the Commission approved a new five-year PBR plan for Alberta gas and electric distribution utilities ${ }^{165}$ starting January 1, 2018. The Commission directed utilities to file "rebasing" applications to establish going-in rates for the new PBR plan. In its rebasing application, EPCOR applied to recover the remaining undepreciated capital costs associated with the meters that had been replaced with AMI meters through the recovery of the remaining depreciation expense, either according to the existing depreciation study or an on accelerated basis. ${ }^{166}$

EPCOR acknowledged that there were no new facts since the Commission had originally determined that the remaining undepreciated capital cost was for the account of EPCOR's shareholder. ${ }^{167}$ It did argue, however, that two recent Supreme Court of Canada decisions had provided the Commission with greater flexibility regarding the recovery of costs associated with stranded assets, and that the Commission had greater discretion to depart from the principles set out in the UAD Decision. ${ }^{168}$

The two decisions to which EPCOR referred are Ontario (Energy Board) v. Ontario Power Generation ${ }^{169}$ and ATCO Gas and Pipelines Ltd v. Alberta (Utilities Commission). ${ }^{170}$

From 1 January 2013 to 31 December 2017. See Rate Regulation Initiative - Distribution PerformanceBased Regulation (12 September 2012), 2012-237, online: AUC <www.auc.ab.ca/regulatory documents/ProceedingDocuments/2012/2012-237.pdf $>$.

EPCOR Distribution \& Transmission Inc - 2014 PBR Capital Tracker True-Up and 2016-2017 PBR Capital Tracker Forecast (7 February 2016), 20407-D01-2016 at para 615, online: AUC <www. auc.ab.ca/regulatory documents/ProceedingDocuments/2016/20407-D01-2016.pdfs.

Ibid at para 617. This allowed EPCOR to recover \$2.54 million of a total of $\$ 11.5$ million of undepreciated capital costs: Rebasing for the 2018-2022 PBR Plans for Alberta Electric and Gas Distribution Utilities - First Compliance Proceeding (5 February 2018), 22394-D01-2018 at para 376, online: AUC <www.auc.ab.ca/regulatory documents/ProceedingDocuments/2018/22394-D01-2018. pdf $>$ [AUC Decision 22394-D01-2018].

It was originally expected that customers would receive the benefit of these costs savings when EPCOR's rates were rebased at the end of the PBR term. However, as a result of the rebasing mechanism the Commission approved, not all of the cost savings were passed on to customers: AUC Decision 22394-D01-2018, ibid at paras 115-22.

2018-2022 Performance-Based Regulation Plans for Alberta Electric and Gas Distribution Utilities (16 December 2016), 20414-D01-2016 at para 18, online: AUC <www.auc.ab.ca/regulatory_documents/ ProceedingDocuments/2016/20414-D01-2016.pdf $>$.

AUC Decision 22394-D01-2018, supra note 163 at para 274.

Ibid at para 375 .

Ibid at paras 378-79.

Ontario (Energy Board) v Ontario Power Generation Inc, 2015 SCC 44 [OPG].

ATCO Gas and Pipelines Ltd v Alberta (Utilities Commission), 2015 SCC 45 [ATCO Pension]. 
Both are summarized below. EPCOR argued that according to OPG, the Commission could apply the "'prudent investment test' as a tool available to the regulators to 'soften the potentially harsh effects of the used and useful test." "171 EPCOR also referred to a passage from ATCO Pension where the Court indicated that a regulator has the discretion to apply a variety of tools and evidence in determining whether costs are prudent. ${ }^{172}$

EPCOR argued that "the public interest in this case would be best served by allowing [EPCOR] to continue to recoup its prudent investment in the conventional meters from ratepayers," considering that the Commission's initial interpretation of the law would create a powerful disincentive to utilities to pursue innovative projects like AMI where to do so would risk stranding capital. ${ }^{173}$

The Commission rejected EPCOR's argument, referring again to the corporate and property law principles from Stores Block and the emphasis in the UAD Appeal that "[f]airness to customers requires that the rate base include only assets used or to be used for [utility service]." ${ }^{174}$ The Commission concluded that it did not have the discretion to depart from the principles set out in the UAD Decision. ${ }^{175}$

\section{a. $\quad O P G$}

In $O P G$, the Supreme Court considered a decision of the Ontario Energy Board (OEB) that disallowed $\$ 145$ million in labour compensation costs related to the operations of Ontario Power Generation (Ontario Power), on the grounds that these costs were out of step with costs of other entities in the regulated power generation industry. ${ }^{176}$ The thrust of Ontario Power's argument was that the OEB was legally required to apply a no-hindsight prudent investment test such that Ontario Power could recover all of its prudently committed or incurred costs. ${ }^{177}$ The Ontario Court of Appeal agreed that such a test should be applied, because the costs were committed and were costs that, by law, Ontario Power could not manage. ${ }^{178}$ However, the majority of the Supreme Court allowed the appeal, reinstating the OEB decision. ${ }^{179}$

The Supreme Court applied a reasonableness standard of review on the basis that the appeal turned on the interpretation of the OEB's home statute. ${ }^{180}$ The Supreme Court noted that the legislation did not "prescribe the methodology the [OEB] must use to weigh utility and consumer interests" in determining what costs are "just and reasonable." ${ }^{181}$ Instead, the

AUC Decision 22394-D01-2018, supra note 163 at para 378, citing OPG, supra note 169 at para 91. ATCO Pension, supra note 170 at para 47.

AUC Decision 22394-D01-2018, supra note 163 at para 380.

Ibid at para 391 .

Ibid at para 392.

OPG, supra note 169 at para 1 .

Ibid at para 86.

Ibid at para 37.

Ibid at 10

O Reg 53/05; OPG, ibid at para 73. Contrast this with the correctness standard applied by the Supreme Court in Stores Block, supra note 1, which also turned on the interpretation of a regulator's home statute. $O P G$, ibid at para 77 . 
legislation gave the OEB explicit discretion as to the methodology to determine just and reasonable rates. ${ }^{182}$ Notably, this explicit discretion is absent in the Alberta legislation.

The Court completed a review of both US and Canadian jurisprudence and legislation. It found that a no-hindsight prudent investment test was only mandatory when required by legislation. ${ }^{183}$ The Court concluded that the no-hindsight prudent investment test is widely used and is a valid tool that regulators may use when assessing whether costs are just and reasonable. ${ }^{184}$ However, the Court found no support in the legislation of the OEB or the relevant jurisprudence that the $\mathrm{OEB}$ was required to use such a test, concluding as follows:

As discussed above, where a statute requires only that the regulator set "just and reasonable" payments, as the Ontario Energy Board Act, 1998 does in Ontario, the regulator may make use of a variety of analytical tools in assessing the justness and reasonableness of a utility's proposed payment amounts. This is particularly so where, as here, the regulator has been given express discretion over the methodology to be used in setting payment amounts: O. Reg. 53/05, s. 6(1). ${ }^{185}$

On this basis the Supreme Court determined that the OEB's characterization of the $\$ 145$ million in compensation costs as a mix of forecast and committed costs, and its decision not to apply the no-hindsight prudent investment test when deciding to disallow OPG's costs, were reasonable. ${ }^{186}$

\section{b. ATCO Pension}

ATCO Pension was heard together with OPG, and it concerned the Commission's denial of the recovery of pension costs of ATCO Gas and ATCO Electric (ATCO Utilities). ${ }^{187}$ At first instance, the Commission had found that ATCO Utilities' practice of awarding an annual cost of living adjustment (COLA) of 100 percent of the consumer price index (CPI) was not reasonable in light of evidence that other entities set the COLA between 50 and 75 percent of CPI. ${ }^{188}$ The ATCO Utilities appealed the Commission's decision to the Court of Appeal, arguing that the use of the word "prudent" in the EUA and GUA necessitated the use of the no-hindsight prudent investment test. The Alberta Court of Appeal disagreed, dismissing the appeal. ${ }^{189}$

While the facts of OPG were different, the Supreme Court in ATCO Pension noted that both cases involved the issue of whether a regulator is required to apply the no-hindsight prudent investment test in assessing a utility's costs. ${ }^{190}$ As it did in OPG, the Supreme Court in ATCO Pension dismissed the ATCO Utilities' appeal on the basis that the relevant statutory framework did not impose a methodology on the Commission, and the

Ibid at para 78 (the legislation in question was the Ontario Energy Board Act, 1998, SO 1998, c 15, Schedule B [OEBA]).

$O P G$, ibid at paras $102-104$.

Ibid at paras 102-103.

Ibid at para 103 .

Ibid at paras 116-17.

ATCO Pension, supra note 170 at paras 1-2.

Ibid at para 1.

Atco Gas and Pipelines Ltd v Alberta (Utilities Commission), 2013 ABCA 310.

ATCO Pension, supra note 170 at para 2. 
methodology used by the Commission and its application was reasonable in light of the nature of the costs in question. ${ }^{191}$

The Supreme Court began with a review of the relevant legislation (the EUA for ATCO Electric and the GUA for ATCO Gas), noting that the Commission was required to set just and reasonable rates. ${ }^{192}$ The Supreme Court recognized that unlike the OEBA in OPG, the $E U A$ and GUA do not include a direct grant of methodological discretion with respect to setting just and reasonable rates. However, like the $O E B A$, neither of the Alberta statutes impose a specific methodology, notwithstanding the use of the word "prudent" in the relevant statutes. ${ }^{193}$

The Supreme Court made a distinction between "prudent" costs and "prudently incurred costs." Prudent costs must be reasonable for recovery by the utility at the time they are recovered. ${ }^{194}$ Prudently incurred costs, on the other hand, "speak more directly to a utility's decision to incur costs at the time the decision was made" and "may more directly implicate the no-hindsight approach urged by the ATCO Utilities in this case than language that merely speaks of "prudent costs." "I95 It is fair to say that this distinction can be regarded as a marked departure from the generally understood principles of the regulatory compact, and the principle that it is fundamentally unfair to decide whether a decision was prudent based on facts or considerations that the utility did not know and could not reasonably have known at the time it made the decision (or incurred a particular cost).

\title{
VII. The AUC Appears Unlikely to Change Its Position
}

Recently, in AUC Decision 22394-D01-2018, the Commission concluded that it has no discretion to grant relief from the principles set out in the UAD Decision. The Commission stated:

\footnotetext{
While the Commission acknowledges that its decision has the potential to have a negative effect on the PBR incentives to innovate and pursue reductions in costs, the Commission has not been persuaded by EPCOR's arguments that such discretion exists in the present statutory context as interpreted by the courts and in light of the application of the corporate and property law principles applied by the courts. In this regard, the Commission notes that the court in the Fortis decision, at paragraph 76, stated the following:
}

76. The Commission, and this Court, are bound by Stores Block and the subsequent decisions from this Court. Only legislative amendment, reconsideration, or a reversal of Stores Block by the Supreme Court of Canada can change that. ${ }^{196}$

The Commission has been a staunch proponent of the benefits of incentive regulation (such as PBR) over traditional cost of service regulation since it approved its first incentive

\author{
Ibid at para 5 . \\ Ibid at para 29 \\ Ibid at para 32. \\ Ibid at para 38 . \\ Ibid at para 39 \\ AUC Decision 22394-D01-2018, supra note 163 at para 392.
}


framework almost a decade ago. ${ }^{197}$ In considering PBR plan proposals, the Commission has focused heavily on maximizing desirable incentives. The acknowledgment in AUC Decision 22394-D01-2018 that its UAD principles have a potential negative effect on PBR incentives must have been a difficult one for the Commission to make, and it is tempting to infer that the Commission regarded the denial of the AMI-related relief requested by EPCOR as an undesirable precedent, but that it felt unable to do otherwise.

In drawing the conclusion that it had no discretion to depart from the principles set out in the UAD Decision, the Commission arguably adopted too narrow a view of its own authority and jurisdiction. After reviewing the Commission's UAD Decision, the Court of Appeal concluded that the treatment of stranded assets is, at its foundation, a policy issue, and that the Commission's policy choice was a legitimate and defensible one. ${ }^{198}$ The Court of Appeal applied the reasonableness standard of review rather than the correctness standard. ${ }^{199}$ Thus, the Court of Appeal's decision means that the Commission's findings and principles in the UAD Decision fell within a reasonable range of outcomes, not that they were the only correct outcome. Indeed, this is clearly illustrated by the Court's statement that the Commission's principles were a policy choice. ${ }^{200}$ Furthermore, OPG and ATCO Pension stand for the proposition that where (as is the case with the UAD principles) the governing statutes do not prescribe a methodology or test, the Commission has very broad authority and jurisdiction to use a wide variety of methodologies and tools, subject to the Commission's overarching public interest mandate.

Even if we assume that it was reasonable for the Commission to interpret Stores Block as extending to the recovery of costs associated with stranded assets, that does not mean that every policy choice the Commission made in the UAD Decision is immutable. For example, the "extraordinary retirement" test for stranded asset cost recovery was created by the Commission. There is nothing in Stores Block that speaks to extraordinary or ordinary retirements (or stranded assets, for that matter). The Commission was likely attracted to the apparent similarity between the statutory references to dispositions outside the ordinary course of business (which was considered in Stores Block) and the accounting or depreciation concept of extraordinary retirements. However, as discussed below, the extraordinary retirement test has serious flaws. The creation of the extraordinary retirement test was one of the "policy choices" the Commission made in the UAD Decision. The simple fact that the Court of Appeal held that the Commission's policy choices were reasonable does not mean that those choices are permanent, particularly if there is evidence that in practice some of the choices lead to unreasonable and unfair outcomes and are not in the public interest. Nevertheless, the Commission has clearly signaled that it is not going to change its approach in the absence of legislative amendments.

ENMAX Power Corporation - 2007-2016 Formula Based Ratemaking (25 March 2009), 2009-035, online: AUC <www.auc.ab.ca/regulatory_documents/ProceedingDocuments/2009/2009-035.pdf> . UAD Appeal, supra note 117 at para 171 .

Ibid at para 46.

Ibid at paras 171-72. 


\title{
VIII. IN ITS INTERPRETATION OF STORES BLOCK THE AUC STANDS Alone
}

The Supreme Court of Canada is, of course, the highest court in Canada, and its decisions apply across the country. Yet the Commission is the only Canadian utility regulator to have interpreted Stores Block as requiring utilities to bear the financial risk of stranded assets. In the recent Commission proceeding to determine utility cost of capital for $2018-2020,{ }^{201}$ one of the cost of capital experts stated:

\begin{abstract}
The [UAD] Decision is one of the most impactful decisions in North American utility regulation of the last decade and its treatment of stranded costs runs counter to one of the basic tenets of utility regulation - to grant cost recovery of and a return on prudent utility investment. What was once relatively assured in Alberta (that utility investors would have a reasonable opportunity to recover their costs, including a fair return on those costs), is now dependent on the circumstances of whether the asset remains "used and useful" for its depreciable life - an unknown at the time when the investment was made and generally outside of the investor's control. ${ }^{202}$
\end{abstract}

The same expert also stated:

I know of no other regulatory body in Canada or the United States that has taken a similar approach to that taken by the Commission with respect to the Stores Block Decision, and in particular the extent to which the Commission has disallowed cost recovery for assets that have been deemed by the regulator as prudent and useful for utility service, were placed into service, but were later stranded before the end of their useful life. $^{203}$

So why does the Commission's UAD Decision stand alone? We are not aware of any other Canadian utility regulator that initiated a proceeding to specifically consider the implications of Stores Block, so we are largely left to speculate. However, it is clear, in our view, that the difference in regulatory treatment cannot be justified solely by differences in provincial legislation.

Stores Block was not about stranded assets. Stores Block considered and interpreted a statutory provision that required regulatory approval for the disposition of utility assets outside the ordinary course of business, but did not provide any further guidance to the regulator. It appears that other Canadian regulators have interpreted Stores Block narrowly, confining it to dispositions of utility assets outside the ordinary course of business; that is, to circumstances where a utility voluntarily sought to transfer ownership of utility assets to a third party.

A significant difference between the utility landscape in Alberta and other provinces may also have contributed to the different interpretation of Stores Block in other provinces.

2018 Generic Cost of Capital Proceeding (2 August 2018), 22570-D01-2018, online: AUC <www.auc. ab.ca/regulatory_documents/ProceedingDocuments/2018/22570-D01-2018.pdf $>$ [AUC Decision 22570D01-2018].

Ibid (Evidence, Prepared direct testimony of James M Coyne, Exhibit 22570-X0131) at 84 [Exhibit 22570-X0131].

Ibid (Evidence, Rebuttal testimony of James M Coyne, Exhibit 22570-X775) at 55. 
Alberta has a relatively high concentration of investor-owned gas and electric utilities. There is no equivalent to BC Hydro, Hydro Québec, or Manitoba Hydro in Alberta. In provinces with large Crown Corporation utilities, neither the government nor the regulator may have had any appetite to interpret Stores Block as shifting the risk of stranded assets to the utility since that would require the provincial government to absorb any losses associated with stranded assets. That does not explain Ontario, though. Regulated by the OEB, Hydro One is Canada's largest electricity transmission and distribution utility. Its service territory covers approximately 75 percent of Ontario, and it is a publicly-traded corporation. ${ }^{204}$ The OEB is no shrinking violet, and it has demonstrated that it is prepared to make significant cost disallowances regardless of utility ownership, as OPG demonstrates. ${ }^{205}$

The Commission's approach may have been influenced by the extraordinary amount of litigation regarding the treatment of utility assets that prompted and more notably, followed Stores Block. It may be that the Commission was looking for a way to provide some certainty and pre-empt future appeals. If certainty was the Commission's goal, it was, arguably, not successful.

\section{STranded Asset Risk - Where Do We Stand Today AS A RESUlt OF THE STORES BLOCK LINE OF CASES?}

Broadly speaking, the Commission has two core functions. The first function is to approve utility rates. The second is to approve the construction and operation of transmission facilities. As is the case in most, if not all, North American jurisdictions, the relevant legislation in Alberta governing utility rates requires the Commission to provide utilities with a reasonable opportunity to recover the prudent costs and expenses of providing utility service and a fair return. In applications to construct and operate transmission facilities, the Commission must determine whether the proposed facilities are in the public interest. If the Commission concludes that they are, in the utility's subsequent rate applications, the Commission assesses whether the actual capital expenditures related to the facilities were prudent. The amount that the Commission determines is prudent is added to the utility's rate base. Before the UAD Decision, the expectation (based on many decades of experience) was that once a capital expenditure was included in rate base, recovery was assured, even if the underlying asset was prematurely removed from service.

Alberta utilities have a statutory obligation to provide service, and this requires them to construct and replace facilities. The cost of these facilities is recovered through depreciation expense over very long periods of time - 40 years is not uncommon. The prudence of the capital expenditure is determined by the regulator at or near the time the expenditure is made. The long-standing understanding was that once the regulator determined that a capital expenditure was prudent, recovery of those costs over the subsequent decades was assured, and the issue of prudence would not be revisited. The UAD Decision effectively changed the rules for cost recovery part-way through the depreciable life of utility investments. 
Today, if a utility asset is prematurely removed from service in Alberta, whether the utility can continue to recover its investment turns on whether the removal from service was an extraordinary retirement. As discussed below, this has increased risk and uncertainty, and the application of the extraordinary retirement test has some troubling and unfair implications.

\section{A. The EXTRAORdINARY RETIREMENT TEST - FUTURE RECOVERY DEPENDS ON RETIREMENT HiSTORY}

In order to determine whether a utility may recover undepreciated capital costs associated with assets that have been prematurely removed from service, the Commission adopted the extraordinary retirement test. ${ }^{206}$ This is an accounting or depreciation concept, and it was not used nor referred to in Stores Block or any other decision prior to the UAD Decision.

As described above, applying the principles of ordinary and extraordinary retirements, the Commission has permitted utilities to recover the costs associated with stranded assets, if the specific mode of retirement was considered and accounted for in the utility's depreciation study and the resulting depreciation rates. So, for example, ATCO Electric was not able to recover the undepreciated costs of assets destroyed by the Slave Lake fire, but ATCO Gas was able to recover the undepreciated costs of assets destroyed by the 2013 flood. The difference? A past ATCO Gas depreciation study had considered and incorporated events of a similar nature to the 2013 flood, namely the 2005 Southern Alberta Flood and the 1987 tornado, in determining depreciation rates. ${ }^{207}$ Conversely, no prior fire event of a similar magnitude to the Slave Lake Fires ( $\$ 23.7$ million in damage) had been considered in ATCO Electric's prior depreciation studies in determining the depreciation rates. Only events that had damage in the range of $\$ 1$ million to $\$ 2$ million had been considered.

This "ordinary vs. extraordinary" distinction means that a utility must forego cost recovery for assets stranded by a mechanism or event of a type and magnitude that the utility has not experienced in the past, but that it can recover stranded asset costs where the assets are stranded by a mechanism or event of a type and magnitude that the utility has experienced in the past. Effectively, this means that Alberta utilities will be able to recover the cost of assets destroyed by the second natural disaster of a particular type and magnitude, but not the first. Suppose there is widespread flooding in Alberta in 2018. For a utility that was affected by the 2013 flood, and which incorporated the resulting retirement experience into its depreciation study and resulting depreciation rates, the destruction of assets in the 2018 flood should be an ordinary retirement, such that it can recover the remaining undepreciated costs of the destroyed assets, assuming the 2018 floods were of a similar magnitude. However, if a neighbouring utility that was not affected by the 2013 flood is affected by the 2018 flood, the retirement experience of the 2013 flood would not be reflected in the second utility's depreciation rates. For it, the destruction of assets in the 2018 flood would be an extraordinary retirement. This is arguably unfair and arbitrary, and it is difficult to see how the principles laid out in Stores Block mandate such an outcome. 
To date, the stranded asset costs that utility shareholders have had to absorb have been relatively modest. The largest disallowance to date is the $\$ 8.96$ million undepreciated cost of the meters replaced by EPCOR. ${ }^{208}$ To put this in perspective, EPCOR's 2016 mid-year net rate base was $\$ 987.2$ million. ${ }^{209}$ Thus the largest disallowance to date, while not a mere paper cut, was not a mortal wound, either. However, the most significant stranded asset costs are likely to result from major natural disasters or severe weather. These losses could be ruinous and could threaten the survival of an affected utility. Consider, for example, the severe January 1998 ice storm in Eastern Canada that destroyed 1,500 pylons, 26,000 poles and 4,500 transformers in Hydro Québec's system alone. ${ }^{210}$ If something like this were to occur in Alberta, whether a utility could recover the undepreciated cost of destroyed assets would depend on whether a similar event had affected the utility in the past and had thus been reflected in its depreciation rates. Those utilities for whom the destruction of facilities would be an extraordinary retirement might not survive if the UAD Decision is applied as it has been to date.

AltaLink Management Ltd. (AltaLink), which owns and operates one of the two largest transmission systems in Alberta, attempted to change the way it carries out depreciation studies in order to mitigate the arguably arbitrary outcomes that application of the extraordinary retirement test produces. In the dense and peculiar language of depreciation, AltaLink suggested that depreciation studies should no longer rely on gradualism and moderation and should instead have an "increased emphasis of depreciation parameters to fully reflect the future expectations of average service life and net salvage expectations." 211 In other words, AltaLink wanted its depreciation study to reflect more of the possible ways in which assets could be stranded. The Commission denied AltaLink's proposal, stating that gradualism and moderation "continue to be long held tenets in utility depreciation that mitigate potential errors that could otherwise result from implementing results without gradualism and moderation." 212

\section{B. THE EXTRAORDINARY RETIREMENT TEST - IMPLICATIONS FOR INVESTMENT IN NEW TECHNOLOGY}

The extraordinary retirement test also has implications for technological innovation, and has the potential to stifle voluntary utility investment in new technologies. EPCOR made this point in connection with its AMI investment, although EPCOR ultimately proceeded with its AMI program in spite of the significant stranded asset cost it incurred. Technological developments in all aspects of power systems are ongoing. Some developments and technologies can be adopted over time as existing equipment is replaced. However, other

AUC Decision 22394-D01-2018, supra note 163 at paras 376-77.

AUC Decision 22570-D01-2018, supra note 201 (Evidence, EPCOR summary of return on rate base, Exhibit 22570-X0204) at 2.

Lesley-Ann Dupigny-Giroux, "Impacts and Consequences of the Ice Storm of 1998 for the North American North-east" (2005) 55:1 Weather 7 at 13.

AltaLink Management Ltd - 2015-2016 General Tariff Application (9 May 2016), 3524-D01-2016 at para 289, online: AUC <www.auc.ab.ca/regulatory_documents/ProceedingDocuments/2016/3524-D012016.pdf $>$.

Ibid at para 306. 
technologies, such as smart meters, need to be implemented en masse. ${ }^{213}$ And still other technologies may need to be implemented at a particular time in response to new legislated obligations or requirements.

As a result of the UAD Decision, utilities may be understandably reluctant to make avoidable investments that have the potential to result in material stranded asset costs. Electric utilities have a statutory obligation to make decisions about building, upgrading and improving the electric distribution system for the purpose of providing safe, reliable, and economic service. ${ }^{214}$ Gas utilities have a statutory obligation to furnish safe, adequate, and proper service and maintain property and equipment in such condition as to enable the owner to do so. ${ }^{215}$ However, there are likely few, if any, technological advances or innovations that must be adopted to comply with these obligations.

There may, however, be investments in new technology that utilities cannot avoid. Since 2015, the Alberta Government has implemented an aggressive climate change policy, the Climate Leadership Plan (CLP). Under the CLP, the government has set a number of goals to "green" Alberta's traditionally carbon-based electric industry, including setting a target of having 30 percent of Alberta's power needs met by renewable energy, and mandating that by 2030 there will be no emissions from coal-fired generation. ${ }^{216}$

In order to achieve the 30 percent renewable energy goal, the Alberta Government has indicated a desire to increase the extent of microgeneration and distributed generation in the Province. ${ }^{217}$ Distributed generation generally refers to small-scale (up to $20 \mathrm{MW}$ ) generation projects that are connected directly to the lower voltage distribution system, rather than to the higher voltage transmission system. Distributed generation generally uses small-scale technologies such as small natural gas generators and combined heat power plants, as well as renewable technologies such as solar, wind and hydro power, to generate power at or close to the end-user. Such projects can include "behind the meter" microgeneration (less than 5 MW) projects like solar panels installed on a customer's home, as well as larger projects built primarily to sell electricity onto the grid.

However, integrating distributed generation into the grid poses challenges for electric distribution utilities, whose systems have been designed to accommodate one-way power flows from substations to customers. Distributed generation enables distribution customers to both consume power from, and potentially supply power to, the grid, creating a bidirectional flow of electricity on distribution systems. Thus, the widespread adoption of distributed generation will require significant investment in so-called "smart grid" technology (including smart meters), and may result in significant stranding of assets.

Assume that the life of a meter is 40 years. It would therefore take 40 years to replace all existing meters with smart meters if the utility only replaced fully-depreciated meters. However, that would also mean that the benefits of smart meters (system-wide implementation of time-of-use rates, for example) could not be fully realized for 40 years. By that time, the smart meters might themselves be obsolete.

EUA, supra note 102 , s $105(1)(\mathrm{b})$.

GUA, supra note 16 , s $35(\mathrm{~b})$.

Government of Alberta, "Climate Leadership Plan," online: $<$ https://www.alberta.ca/climate-leadershipplan.aspx>.

Government of Alberta, "What is Micro-Generation?" online: <https://www.energy.alberta.ca/Au/ electricity/AboutElec/pages/MicroGen.aspx>. 
In March 2017, the Alberta Government tasked the AUC with conducting a broad inquiry into matters relating to distributed generation in Alberta. ${ }^{218}$ The Commission sought input and received evidence from Alberta electric utilities, the Alberta Electric System Operator (AESO), and other interested stakeholders and members of the public. ${ }^{219}$

One of the issues raised by the electric utilities in the proceeding was their potential liability for stranded asset costs associated with the development of distributed generation in accordance with the principles set out by the Commission in the UAD Decision. ${ }^{20}$ The electric utilities indicated that they were unwilling to assume such liability in order to meet the government's policy objectives, reiterated their concerns with the stranded asset risk implications of the UAD Decision, and called for statutory change to address these concerns. ${ }^{221}$ For example, FortisAlberta Inc. submitted:

FortisAlberta recognizes that the future development of Alberta's electric distribution grid will potentially include the deployment of new asset types and technology. It is possible that certain of these deployments may cause other existing assets to be subject to sudden obsolescence because of lack of retro-compatibility, or other factors. These potential occurrences currently represent a risk of existing system assets being stranded, or otherwise deemed to be "extraordinary retirements", in accordance with the principles established in the Commission's Utility Asset Disposition decision (UAD Decision).

The Climate Change Initiative demonstrates the inadvisability of leaving in place, without governmental consideration of and possible statutory revision to, the constraints and risks placed upon utilities by the UAD Decision. In FortisAlberta's submission, it would be contrary to a fair interpretation of the regulatory bargain if it, and other utilities, were to be required to make substantial investments to further the objects of the Climate Leadership Plan, while exposing such investments to potential non-recovery in accordance with UAD Decision principles. ${ }^{222}$

Following the proceeding, the AUC prepared a report for the government that set out its various findings in relation to the matters covered in the proceeding. The Commission provided its final report to the Minister of Energy on 29 December $2017 .^{223}$

The Alberta Government responded to similar concerns expressed by the owners of coalfired generating units by providing compensation in connection with the CLP. In order to achieve the goal of eliminating coal-fired emissions by 2030, in November 2016, the Alberta Government agreed to make transitional payments to companies that own legacy coal-fired

OC 120/2017 (Alberta Utilities Commisson Act), online: <www.qp.alberta.ca/documents/orders/ Orders in Council/2017/317/2017 120.pdf>.

219 Notice of Review - Regulatory Process Initiated for Electric Distribution System-Connected Generation Review (Distributed Generation Review) (31 March 2017), Proceeding 22534, online: AUC $<$ www.auc.ab.ca/regulatory_documents/ProceedingDocuments/2017/22534.pdf $>$. Alberta Utilities Commission, "Distributed Generation Review: Proceeding 22534," online: AUC $<$ www.auc.ab.ca/regulatory documents/Pages/Distributed-generation-review.aspx $>$ [AUC Proceeding 22534].

$221 \quad$ Ibid.

222 Ibid (Evidence, Further submissions of FortisAlberta Inc, Exhibit 22534-X0284), online: AUC $<$ https:// www2.auc.ab.ca/Proceeding22534/ProceedingDocuments/22534_X0284 2017-09-15FortisAlberta FurtherSubmission_0310.pdf $>$ [footnotes omitted].

223 Alberta Electric Distribution System-Connecterd Generation Inquiry - Final Report (29 December 2017), online: AUC <www.auc.ab.ca/regulatory_documents/Consultations/DistributionGeneration Report.pdf>. 
thermal generation units with operating lives that extend beyond 2030 to compensate them for the "approximate economic disruption to their capital investments."224

It has been reported that the Alberta Government is expected to pay three coal-fired generating plant operators (TransAlta Corp., ATCO Ltd. and Capital Power Corp.) a total of $\$ 97$ million dollars per year until 2030 (\$1.36 billion in total) in exchange for shutting down six coal-fired generation units prior to the end of their expected operating lives. ${ }^{225}$ Thus, in pursuit of the policy objective of achieving zero emissions from coal by 2030, the Alberta Government agreed to compensate operators of coal-fired generation facilities for the stranded value of their generation facilities. ${ }^{226}$ The decision to make these payments was entirely policy driven: the Alberta Government committed to this compensation despite having no statutory or legal obligation to do so, in order to achieve the goal set out in the CLP. Perhaps it is reasonable to assume that the Alberta Government would at least consider taking similar measures to achieve its goal of increasing the penetration of distributed generation.

\section{Is The No-Hindsight Prudence Test Dead?}

When discussing prudence in the context of a utility's rate base, whether a cost is "prudent" such that it is included in rate base must be distinguished from the "no-hindsight prudence investment test."

Whether a cost is prudent is a fundamental part of determining what is included in rate base. This has not been affected by the Stores Block line of cases. Under section 37 of the GUA and section 122 of the EUA, the rates set by the Commission are required to provide gas and electric utilities a reasonable opportunity to recover only their prudent costs. ${ }^{227}$ Thus, investment prudence is a necessary threshold to utility investment cost recovery. As noted in ATCO Pension, under both the GUA and the EUA, the onus rests on a utility to demonstrate that its capital expenditures are prudent. ${ }^{228}$

This threshold prudence requirement is distinct from the "no-hindsight prudent investment test," which was the historical approach to continued inclusion of utility assets in rate base and provided that once a cost is "prudently incurred" it would remain in rate base until the utility fully recovered a return on and a return of its investment. Although it had been historically applied by the Commission's predecessors, in the UAD Appeal, the Alberta Court of Appeal held that neither the GUA nor the EUA mandated the application of the "nohindsight prudence investment test" to a utility's rate base, noting that utilities in Alberta do not have a guaranteed right to recover their prudently incurred costs or to earn a specific rate

Government of Alberta, "Phasing Out Coal Pollution," online: $<$ https://www.alberta.ca/climate-coalelectricity.aspx $>$.

Reid Southwick, "Alberta Reaches \$1.36B Deal to Shut Down Coal Plants," Calgary Herald (24 November 2016), online: <https://calgaryherald.com/business/energy/alberta-reaches-1-36b-deal-toshut-down-coal-plants>.

Ibid.

GUA, supra note 16, s 37; EUA, supra note 102, s 122.

ATCO Pension, supra note 170 at paras $42,45$. 
of return. ${ }^{229}$ In ATCO Pension, the Supreme Court of Canada reviewed the legislative scheme for gas and electric utilities in Alberta, and similarly concluded that the use of the "nohindsight prudence investment test" is not a mandatory requirement in terms of the methodology the Commission applies in determining just and reasonable rates. ${ }^{230}$

As EPCOR argued in AUC Decision 22394-D01-2018, the Supreme Court of Canada in $O P G$ did acknowledge that the no-hindsight prudence investment test was a tool available for regulators to "soften the potentially harsh effects of the used and useful test, which may place onerous burdens on utilities" and could be a useful tool to permit the recovery of costs when to not do so "may imperil the financial health of utilities, and may chill the incentive to make such investments in the first place." ${ }^{231}$ However, this line of argument did not persuade the Commission to use the no-hindsight prudence investment test in AUC Decision 22394-D01-2018, which raises the question: is the no-hindsight prudence investment test dead in relation to utility regulation in Alberta?

The short answer is that, subject to one potential narrow exception, the Commission is not (and has never been) statutorily obliged to apply the no-hindsight prudence test under the GUA or the EUA. Further, based on the Commission's strict interpretation of the property law principles in Stores Block, absent legislative amendment, the Commission appears unlikely to apply the no-hindsight prudence test in the future in relation to rate base investments.

The narrow exception relates to the opening left by the Supreme Court of Canada in OPG and ATCO Pension; namely that the no-hindsight prudent investment test may be required if "prudently incurred" language is used in the legislation. This is the case for electric utility costs that fall under sections 122(1)(d) or 122(1)(g) of the EUA. The Supreme Court referred to these sections in the ATCO Pension case:

By contrast, certain provisions use the adverb "prudently" to qualify the utility's decision to incur costs: s. 122(1)(d) speaks of costs and expenses that are "reasonable and prudently incurred" and s. 122(1)(g) refers to costs and expenses associated with financial arrangements that were "prudently made". Though this case does not call upon this Court to evaluate the types of expenses covered by s. 122(1)(d) or (g), statutory language referring to "prudently incurred" costs appears to speak more directly to a utility's decision to incur costs at the time the decision was made. Such language may more directly implicate the no-hindsight approach urged by the ATCO Utilities in this case than language that merely speaks of "prudent costs". This issue is further complicated for costs arising under s. 122(1)(d), where costs must both "continue to be reasonable and prudently incurred". The proper interpretation of these provisions is a question best left for a case in which the issue arises. ${ }^{232}$

UAD Appeal, supra note 117 at paras 130, 140 (for gas utilities) and paras 157, 164 (for electric utilities). Note that in the UAD Appeal, the Court of Appeal did recognize that a guaranteed prudent cost recovery model would be a permissible interpretation of the EUA but it was not the only one and it held that the Commission's rejection of such a model and application of the used or useful test was reasonable (at para 157). 
Therefore, electric utilities in Alberta may be able to argue that the no-hindsight prudent investment test must be used for costs that fall under sections 122(1)(d) and 122(1)(g) of the EUA. ${ }^{233}$ Practically, however, the application of both these subsections is likely to be very limited. Section 122(1)(d) only applies to assets that were approved by the Public Utilities Board or the EUB prior to the coming into force of the most recent version of the EUA in 2003. Further, as noted by the Supreme Court, the language of section $122(1)(d)$ requires that the costs must "continue to be reasonable and prudently incurred," which suggests a continued reasonableness standard, not a true no-hindsight prudence standard. ${ }^{234}$ Similarly, the application of paragraph $122(1)(\mathrm{g})$ pertains to a narrow category of non-capital related costs to manage financial risk associated with the pool price for power in Alberta. ${ }^{235}$

Therefore, absent future legislative amendment to mandate its use, it does appear that in Alberta the no-hindsight prudent investment test is, if not dead, at least moribund.

\section{NO COMPENSATION FOR STRANDED ASSET RISK}

The UAD Decision shifted the financial risk of stranded assets (or perhaps more precisely, extraordinary retirements) from ratepayers to utility shareholders. As part of its ratemaking function, the Commission must set a fair return, which it does through periodic generic cost of capital (GCOC) proceedings. ${ }^{236}$ In determining a fair return, the Commission applies the so-called fair return standard to set both the ROE and the deemed capital structure or equity ratio. Often likened to a three-legged stool, the fair return standard is made up of three tests: the comparable investment test, the financial integrity test, and the capital attraction test, ${ }^{237}$ as follows:

[A] fair or reasonable return on capital should:

- be comparable to the return available from the application of the invested capital to other enterprises of like risk (the comparable investment standard);

- enable the financial integrity of the regulated enterprise to be maintained (the financial integrity standard); and

- $\quad$ permit incremental capital to be attracted to the enterprise on reasonable terms and conditions (the capital attraction standard). ${ }^{238}$

All three tests must be met. Risk is a relevant consideration in determining both the cost of debt capital and the cost of equity capital. The risk for a utility is made up of business risk and financial risk. Financial risk exists to the extent the company incurs fixed obligations in

\footnotetext{
233 Supra note 102, ss 122(1)(d), 122(1)(g).

234 Ibid, $\mathrm{s} 122(1)(\mathrm{d})$

$235 \quad$ Ibid, s $122(1)(\mathrm{g})$.

236 GUA, supra note 16 , s 37.

237 The fair return standard is drawn from three decisions: Northwestern Utilities Ltd $v$ City of Edmonton, [1929] SCR 186; Bluefield Waterworks \& Improvement Co v Public Service Commission of West Virginia, 262 US 679 (1923); Federal Power Commission v Hope Natural Gas Co, 320 US 591 (1944).

238 TransCanada Pipelines Limited - 2004 Mainline Tolls and Tariff Application (29 April 2005), RH-22004 at 17, online: NEB < https://apps.neb-one.gc.ca/REGDOCS/File/Download/365 091>.
} 
financing its operations. Business risk is the risk inherent in the company's operations regardless of how it is financed. Generally speaking, both debt and equity investors require greater compensation for what they perceive to be higher risk.

Since 2013, Alberta utilities have argued in cost of capital proceedings that the UAD Decision has increased their business risk, but they have not been successful in convincing the Commission to make an explicit adjustment to either the approved ROE or equity ratio to account for this elevated risk. In the 2013 GCOC, the Commission concluded that no adjustment to the allowed ROE or capital structure was warranted to account for the application of the principles in the UAD Decision, primarily because the risk of losses was offset by the potential for gains. ${ }^{239}$

In the 2016 GCOC decision, the Commission agreed there was some incremental, but unquantifiable, increase in risk as a result of the UAD Decision:

\begin{abstract}
Investor perceptions have been evolving since the 2013 GCOC decision, in part, as a result of the principles laid out in the Stores Block decision and subsequent Court of Appeal decisions, as reviewed by the Commission in the UAD decision. The evidence of the Utilities suggested that the regulatory risk component of business risk has increased as a result of these developments. In particular, the uncertainties associated with the interpretation and application by the Commission of the definition of an "extraordinary retirement" in future circumstances creates a marked unknown future potential risk for investors. Interveners highlighted the corresponding enhanced earning opportunities that the affected utilities have by selling capital assets that are no longer required to provide utility service and the trivial nature of disallowances to date. Interveners argued that the facts to date illustrate that gains on sales should at least offset losses due to extraordinary retirements. Therefore, they argued that no additional allowed returns should be awarded because no changes have occurred since the 2013 GCOC proceeding. After reviewing the evidence, the Commission determined above that directionally, regulatory risk for investors in Alberta utilities has increased by some incremental but unquantifiable amount as a result of the Stores Block-UAD line of decisions. ${ }^{240}$
\end{abstract}

However, the Commission found that this incremental increase in risk did not warrant an adjustment to the utilities' approved ROEs.

While the Commission did conclude that the Stores Block line of cases resulted in some "upward pressure on the return expectations of investors since the ... 2013 GCOC decision," it found no evidence on the record that any of the utilities were facing a credit rating downgrade in the foreseeable future. ${ }^{241}$ In the 2016 GCOC Decision, the Commission observed that the distribution utility ROEs for 2013, 2014, and 2015 were, in most cases, higher than the approved ROEs by more than 100 basis points for all three years. ${ }^{242}$ The Commission therefore found there was no basis to conclude that there was an appreciable increase in earnings volatility risk under PBR and, by implication, no appreciable increase

2013 Generic Cost of Capital (23 March 2015), 2191-D-01-2015 at paras 346-51, online: AUC <www. auc.ab.ca/regulatory_documents/ProceedingDocuments/2015/2191-D01-2015.pdf>.

2016 Generic Cost of Capital (7 October 2016), 20622-D01-2016 at para 521, online: AUC <www. auc.ab.ca/regulatory_documents/ProceedingDocuments/2016/20622-D01-2016.pdf>.

Ibid at para 523. This is an unusually narrow test. Credit ratings are important to debt investors, but much less important to equity investors, who are more concerned about ensuring that the return they can earn is commensurate with the risks of the enterprise in which they are investing.

Ibid at para 535 (except for ENMAX Power Corporation and AltaGas Utilities Inc in 2015). 
in earnings volatility due to the Stores Block line of cases (including the UAD Decision) that justified increasing the approved ROEs for Alberta utilities. ${ }^{243}$

The Commission's rationale for not compensating utilities for UAD risk is that the risk of losses arising from stranded assets is balanced by the potential for gains on the disposition of utility assets outside the ordinary course of business. It is certainly true that in the immediate aftermath of Stores Block, there were a number of disposition applications, all of which resulted in gains to the utilities. These applications were for the disposition of surplus land (and in some cases associated structures). Indeed, it is unlikely that there would be a material gain on the disposition of any utility property other than land, which is generally the only non-depreciating asset in rate base. And the gains on dispositions are limited to the difference between the net book value and the sale price (or fair market value). On the other hand, there is arguably no such natural limit on the magnitude of unrecoverable losses associated with stranded assets, since those losses are related to the event that caused the retirement. It is also important to note that the fact that unrecoverable stranded asset costs have to date been relatively modest says nothing about the potential for future catastrophic losses.

In recent years, the ROEs and equity ratios approved by the Commission have been among the lowest in Canada, and lower than the US average, as the following figure shows. $^{244}$ 
FIGURE 1:

APPROVED 2017 EQUITY RETURNS ${ }^{245}$

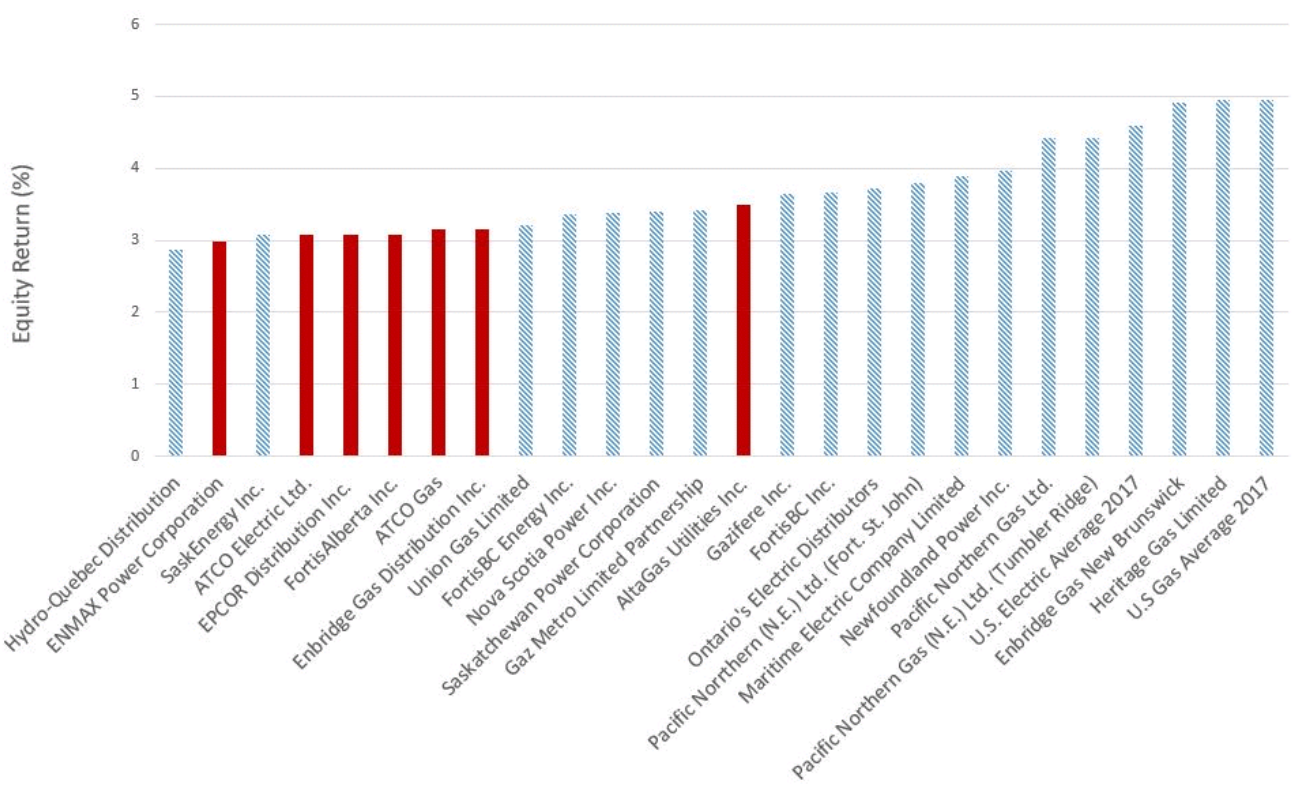

From an investor's perspective, this graph suggests that the Commission believes that Alberta utilities face lower risk than most other Canadian utilities. Yet Alberta utilities face a material stranded asset business risk that no other North American utilities face. ${ }^{246}$ One can certainly see why Alberta utilities question whether the returns approved by the Commission meet the capital attraction and comparable investment tests under the fair return standard.

\section{Conclusion}

Alberta utilities first welcomed the decision of the Supreme Court of Canada in Stores Block on the basis that it clarified that principles of property ownership applied to utility assets, and confirmed that utility shareholders were entitled to any gains that resulted from utility asset dispositions outside of the ordinary course of business. However, it is doubtful that anyone foresaw the tectonic shift in the Alberta utility regulatory landscape that the decision would precipitate.

The graph shows the 2017 equity return for every Canadian gas or electric distribution utility whose cost of capital is set through a litigated proceeding, as well as the average equity return for US gas and electric distributors. Alberta utilities are shown in red. The equity return is the product of the ROE and the equity ratio. For example, an ROE of 10 percent and an equity ratio of 40 percent yields an equity return of 4 percent. We corrected the equity ratio for ENMAX Power Corporation, which was incorrectly shown as 37 percent, when it should have been 36 percent: see ENMAX Power Corporation Application for Finalization of Deemed Equity Ratio for 2016-2017 (27 July 2017), 22211-D01-2017 at para 84, online: AUC <www.auc.ab.ca/regulatory_documents/ProceedingDocuments/2017/22211D01-2017.pdf $>$. Note also that the Commission has approved an equity ratio for AltaGas that is 400 basis points higher than other gas utilities to compensate for its very small size and correspondingly higher risk. 
This failure to anticipate the impact that the Stores Block decision would have on the AUC's interpretation of the GUA and EUA, the concept of prudent utility investment recovery, and the allocation of stranded asset risk in the province was hardly unreasonable. Neither the AUC's conclusion in the UAD Decision that stranded assets must be removed from rate base and that any future extraordinary retirements of such assets must be to the account of shareholders, nor the manner in which it has subsequently applied such principle, can be said to be an obvious or logical application or extension of the ratio of Stores Block (particularly since Alberta is the only jurisdiction to have done so). In this regard, the impact that ATCO Gas' "victory" in Stores Block had on the allocation of stranded asset risks in Alberta serves as an apt demonstration of the "law of unintended consequences."

While we disagree with the Alberta Court of Appeal's determination that the treatment of stranded assets adopted by the Commission in the UAD Decision was a reasonable application of the principles set out in Stores Block, we agree with Justice Paperny's conclusion that the UAD Decision has had "deleterious effects on the regulation of utilities in Alberta." 247 The replacement of the no-hindsight prudent investment test that the Commission and its predecessors had historically applied with the extraordinary retirement test to determine whether a utility is entitled to recover capital costs: (1) gives rise to significant uncertainty in relation to a utility's ability to recover capital investments that were prudent at the time they were made; (2) serves as a disincentive to innovation by utilities where such innovation may result in the stranding of utility assets; and (3) appears to have undermined investor confidence in the Alberta utility sector at a time when the government is seeking to attract investment in Alberta's energy industries. In Alberta, regulated utilities do not themselves invest in renewable energy technology, ${ }^{248}$ but changes to transmission and distribution infrastructure may be required to accommodate significant renewable energy generation.

Based on the current view of the Commission that it has no discretion to depart from the UAD Decision principles, we agree with Justice Paperny that the "deleterious effects" that have been created by the evolution of Alberta regulatory jurisprudence since Stores Block need to be addressed by legislative intervention. ${ }^{249}$ On this front there appears to be some movement. It appears that legislative intervention is likely to be the next chapter in the Stores Block saga.

\section{A NeW ChAPTER?}

On 19 April 2018, the Alberta government introduced Bill 13, entitled Act to Secure Alberta's Energy Future. ${ }^{250}$ Introducing the bill for first reading, the Energy Minister stated:

[I]f passed, this bill will enable the creation of a capacity market, increase investor confidence in Alberta's electricity system by providing policy and regulatory certainty, protect consumers when electric and natural

247 UAD Appeal, supra note 117 at para 161.

248 Power generation is not subject to rate regulation in Alberta, and electric utilities do not own or operate generating facilities in Alberta.

249 UAD Appeal, supra note 117 at para 161.

250 Bill 13, An Act to Secure Alberta's Electricity Future, 4th Sess, 29th Leg, Alberta, 2018 (assented to 11 June 2018), SA 2018, c 10, online: <www.assembly.ab.ca/ISYS/LADDAR_files/docs/bills/bill/ legislature_29/session_4/20180308_bill-013.pdf $>$ [Bill 13]. 
gas service providers breach service quality and compliance standards, and provide more options to Albertans who want to generate their own electricity from renewable or alternative sources. ${ }^{251}$

Among other things, the Bill proposed amendments to the Alberta Utilities Commission $A c t^{252}$ to deal with Stores Block issues. The proposed amendments would have granted the Commission the broad authority, when approving a tariff or setting rates, to allocate certain "direct and indirect" costs and benefits among owners of utilities and their customers. ${ }^{253}$ Specifically, the Commission would have been able to allocate costs (including unrecovered capital investments) and benefits (including proceeds of sale) related to a disposition of property or the removal of property from rate base. ${ }^{254}$ The proposed amendments would also have allowed the Commission to direct that property be removed from rate base if the property is no longer used or required to be used to provide service to the public. ${ }^{255}$ No compensation would have been due to a utility as a result of the Commission allocating all or any portion of benefits to customers. ${ }^{256}$ However, the Commission's authority to deal with costs and benefits was not confined to present or future costs and benefits, but also to those "arising in, or determined in relation to, a prior period, whether or not rates have been finalized for that period." ${ }^{257}$ It is not clear why this retrospective jurisdiction was considered necessary, or in what circumstances it might be used.

In Bill 13, as initially proposed, the only restriction on the Commission's authority to allocate these costs and benefits was that it was required to do so in a manner that gave consideration to the public interest, having regard to any social, economic and environmental effects. ${ }^{258}$ The Commission was to be able to make rules setting out the considerations the Commission would take into account when allocating costs and benefits. ${ }^{259}$

As initially drafted the Bill would therefore have allowed the Commission to allocate both gains or losses realized on the sale or other disposition of utility property, and to determine the treatment of costs associated with property that is removed from rate base. Further, property could be removed from rate base either by the utility or at the direction of the Commission. While the Commission was to have the authority to direct the removal of property that is no longer used or required to be used to provide utility service, it was not required to do so. Presumably, therefore, the Commission would have been able to decide that a stranded asset should remain in rate base and allow the costs associated with that asset to be recovered in the ordinary course.

As initially proposed, the authority granted to the Commission to allocate costs and benefits under Bill 13 was extraordinarily broad. It would have effectively given the Commission carte blanche with respect to the financial consequences of both dispositions

Alberta, Legislative Assembly, Hansard, 4th Sess, 29th Leg (19 April 2018) at 606 (Hon Robert E Wanner), online: <www.assembly.ab.ca/ISYS/LADDAR files/docs/hansards/han/legislature 29/ session 4/20180419_1330_01_han.pdf\#page=16>.

SA $200 \overline{7}$, c A-37.2.

Bill 13, supra note 250, cl 17.1(2).

Ibid, cl 17.1(4).

Ibid, cl 17.1(3)(a).

Ibid, cl 17.1(5).

Ibid, cl 17.1(2)(a).

Ibid.

Ibid, cl 17.1(7)(a). 
and stranded assets. The Commission would have been able to continue to use the extraordinary retirement test if it wished to do so, or it could have chosen to reinstate the TransAlta Formula. The Commission would also have been able to apply different considerations for different causes of premature retirement or based on the materiality of the costs or benefits.

The initially proposed amendments in Bill 13 were a complicated means of dealing with a relatively straightforward issue. Read as a whole, the proposed amendments appeared to seek to give the Commission the broadest possible authority to deal with the financial treatment of dispositions of utility assets and stranded assets (including continuing the status quo and continuing to apply the flawed extraordinary retirement test). As such, while the willingness of the Alberta government to address Stores Block issues through legislative amendments was generally considered by utilities as a positive step, the proposed implementation was regarded as taking a step in entirely the wrong direction. Rather than providing policy and regulatory certainty, at least in the short term, the portions of Bill 13 intended to address the Stores Block issues would have the opposite effect: uncertainty regarding the treatment of stranded asset costs and gains and losses on dispositions would almost certainly have increased.

Capital market reaction to Bill 13 was swift and negative. BMO, for example, expressed disappointment with the UAD-related provisions of Bill 13 and indicated that the bill was "credit negative." 260 Similarly, Alberta utilities were quick to voice their concerns that the legislation as proposed would create significant additional uncertainty and further undermine investor confidence in the Alberta utility sector and that giving the Commission virtually unfettered discretion to deal with stranded assets is, arguably, not the best way to provide policy and regulatory certainty. ${ }^{261}$

On 30 May 2018, the Alberta government amended Bill 13 to remove those portions that were intended to address the Stores Block issues. ${ }^{262}$ Bill 13, without those portions related to the Stores Block issues, was passed on 7 June 2018, and received Royal Assent on 11 June $2018 .^{263}$

Marisa Jones, "Impact of Introduction of Bill 13 to Alberta Utilities," BMO Capital Markets, online: $<$ https://bmo.bluematrix.com/docs/shorthtml/d10f3eac-fda2-4bfa-8f4e-3769a85774a6.html> ("[t]he current wording of the Bill regarding Utility Asset Disposition appears credit negative, as it fails to resolve the potential for outsized losses at a utility in the instance an asset is deemed no longer of use for utility purposes").

261 AltaLink, LP, "Management's Discussion and Analysis" (7 May 2018) at 20, online: $<$ www.altalink.ca/ files/pdf/about/Q1 2018 MDA.pdf>; ENMAX Corporation, "Q1 2018 Interim Financial Report"(May 2018) at 3, online: <https://www.enmax.com/AboutUsSite/Reports/ENMAX-Q1-2018-Financial-Report. pdf>; EPCOR Utilities Inc, "Investor Presentation" (May 2018) at 7, online: <https://www.epcor.com/ about/Documents/epcor-investor-presentation-may-2018.pdf>. Alberta, Legislative Assembly, Amendments to Bill 13 (30 May 2018), online: <www.assembly.ab.ca/ ISYS/LADDAR_files/docs/bills/bill/legislature_29/session_4/20180308_am-013-A1.pdf $>$.

263 Alberta, Legislative Assembly, Bill 13: An Act to Secure Alberta's Electricity Future, 29th Leg, 4th Sess (2018), online: $<$ https://www.assembly.ab.ca/net/index.aspx?p=bills_status\&selectbill=013\&legl=29\& session $=4>$. 
For our part, we suggest that if the Legislature wishes to increase investor confidence, it could deal with the stranded asset issue by expressly requiring the Commission to use the nohindsight prudent investment standard, for example, and making it clear that the recovery of capital investments that were prudent at the time they were made is not at risk. This would put Alberta utilities back on the same footing as utilities in all other Canadian jurisdictions. At this point, however, only time will tell how the Stores Block and UAD saga will end. 